\title{
الرؤية النقدية للمتلقي بين الباقلاني والدراسات الأسلوبية
}

The critical vision of the recipient between Al-Baklani and stylistic studies

\author{
!

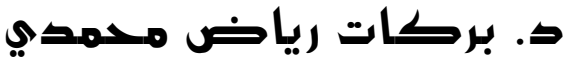 \\ كلية الآداب- جامعة عين شمس- مصر \\ Doi: 10.21608/mdad.2021.167735

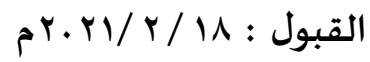

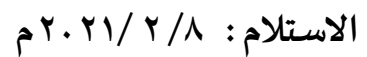

لعل من الإنصاف أن نقرر أن ربط الأسلوب بالمتلقى لم يكن بـالأمر المستحدث

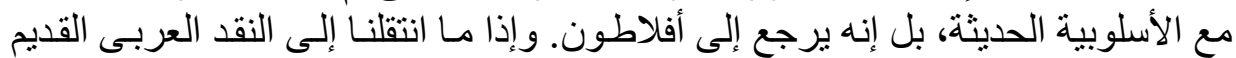

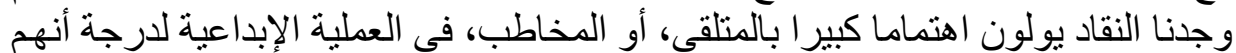

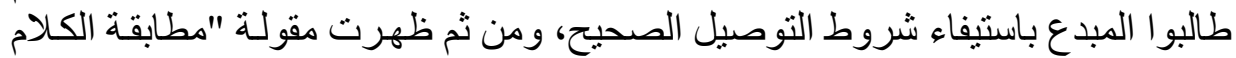

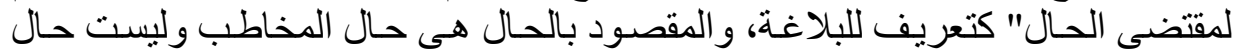

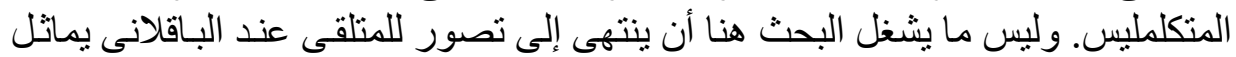

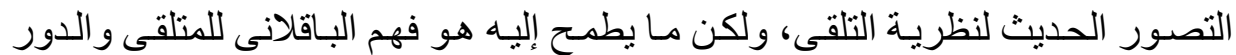

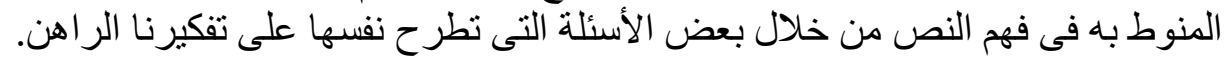
الكلمات المفتاحية: المتلقي_ التلقيـ الباقلاني- إعجاز القرآنـ النظرية الأسلوبية.

\section{Abstract:}

Perhaps it is fair to decide that linking style to the recipient was not an imperative with modern stylistics, but rather that it was due to Plato. If we move to the ancient Arabic criticism, we find that the critics pay great attention to the recipient, or the addressee, in the creative process to the point that they demanded the creator to fulfill the conditions for correct delivery, and then the saying "conformity of speech to the necessity of the situation" appeared as a definition of rhetoric. What is meant by the case is the state of the addressee and not the state of the speaker. What the research is 
concerned about here is not to conclude with a conception of the recipient according to al-Baqlani that is similar to the modern conception of the theory of receptivity, but what it aspires to is the baklani's understanding of the recipient and the role assigned to him in understanding the text through some questions that pose themselves to our current thinking.

Key words: the recipient - the receive - al-Baqlani - the miracle of the Qur'an - the stylistic theory

$$
\text { (1) المتلقى والاهتمام به حديثا: }
$$

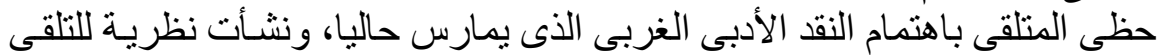

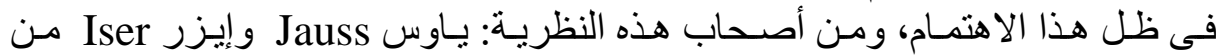

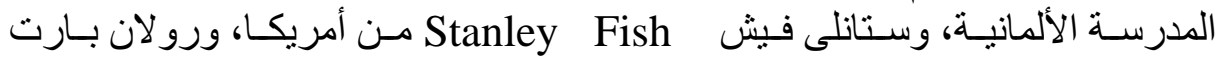

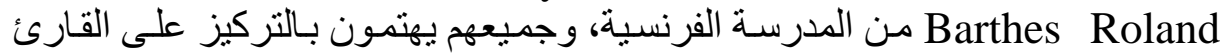

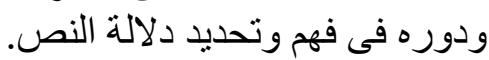

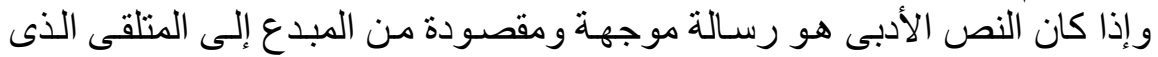

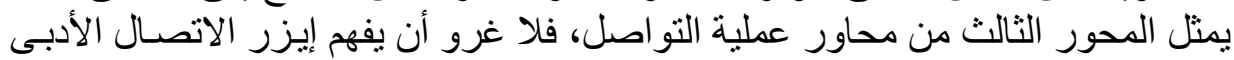

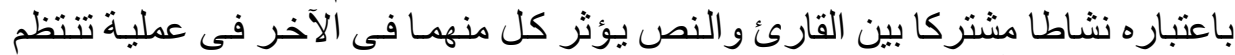

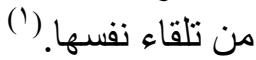
على أن هذا التأثير لن يحدث إلا إذا كان المتلقى على علم بشفرة النص ألصاء أو شفر اتها،

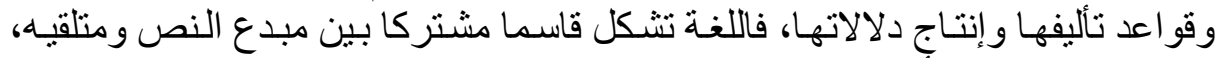

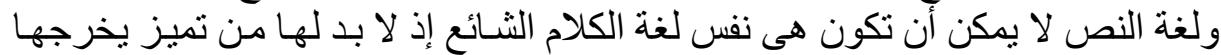

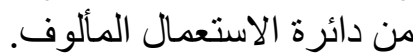

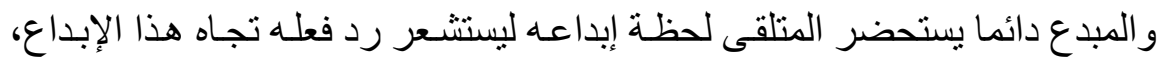

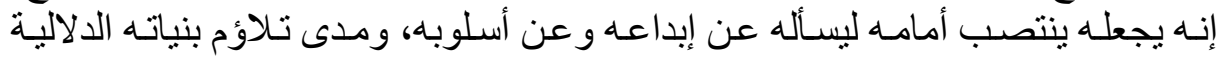

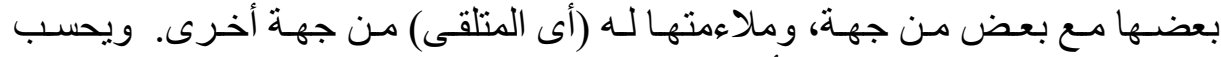

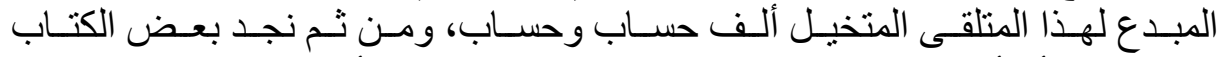

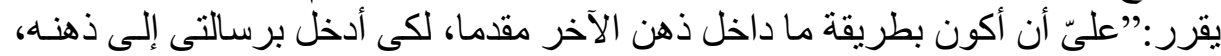

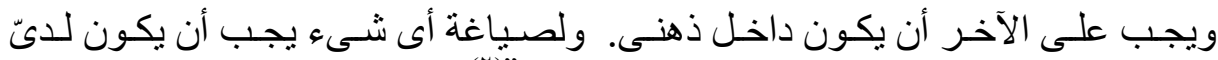

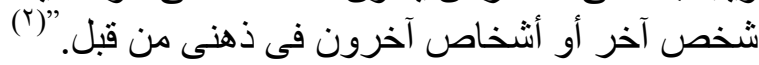

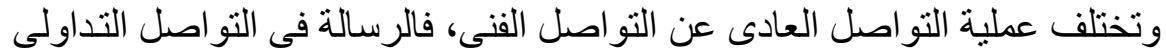

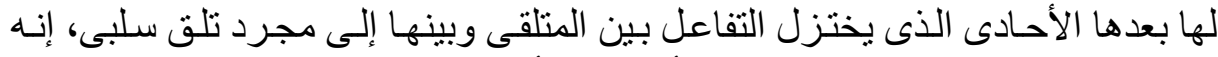

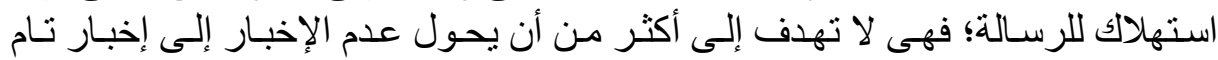




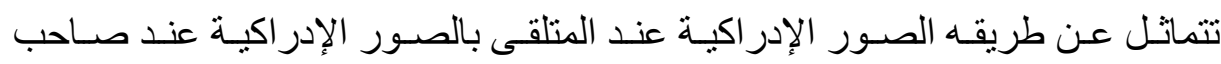

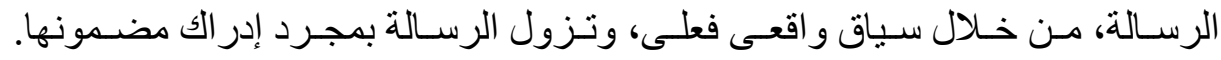

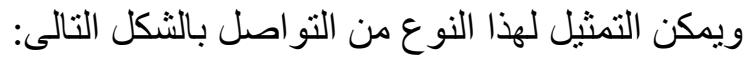

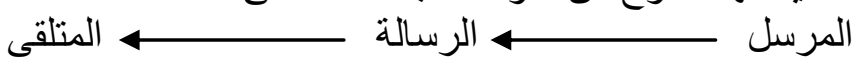

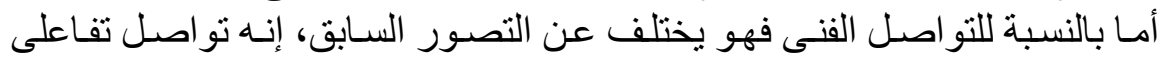

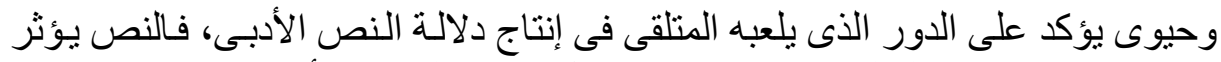

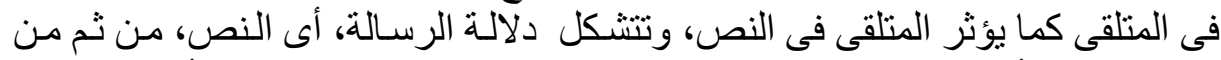

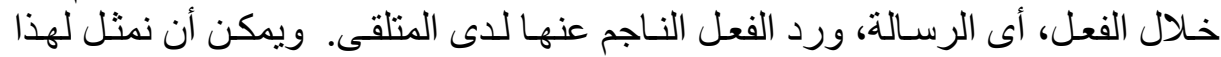

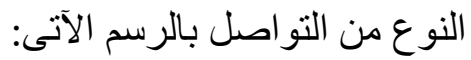

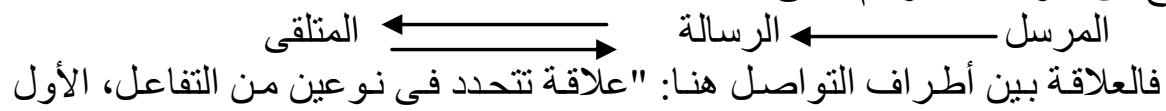

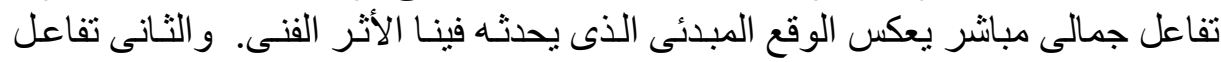

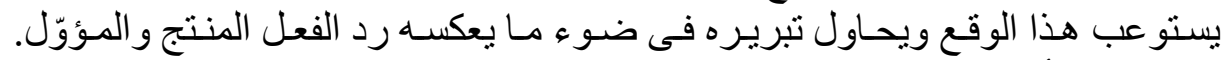

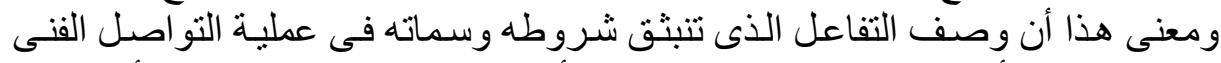

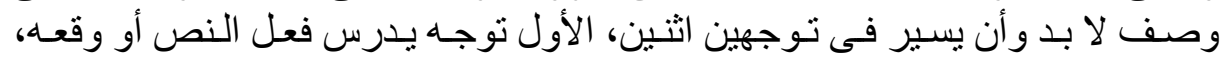

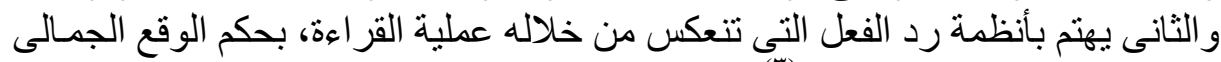

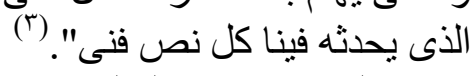

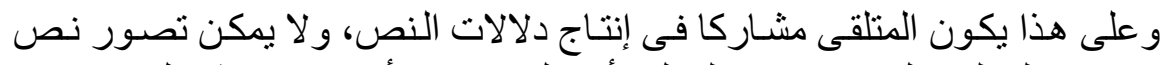

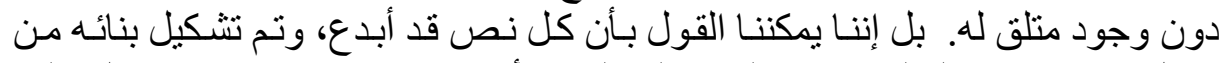

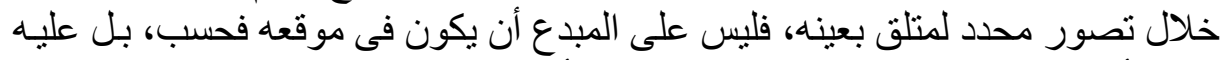

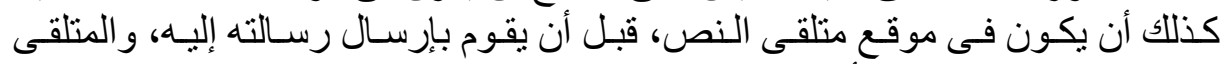

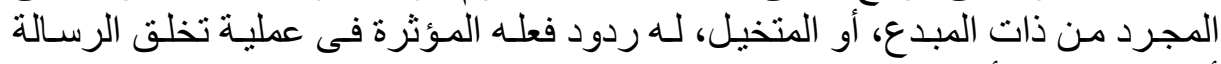

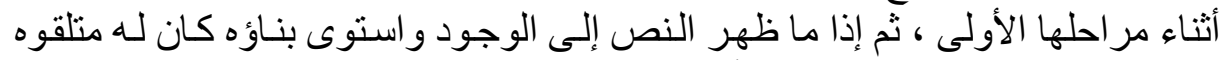

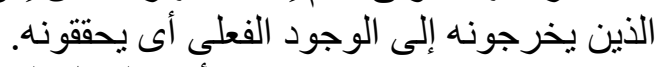

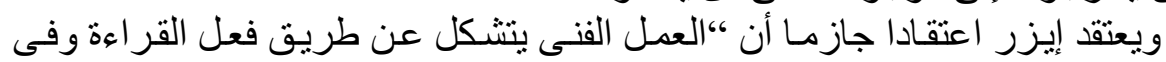

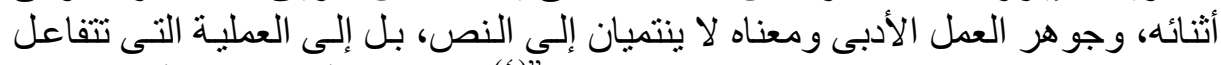

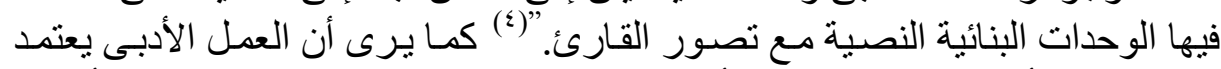

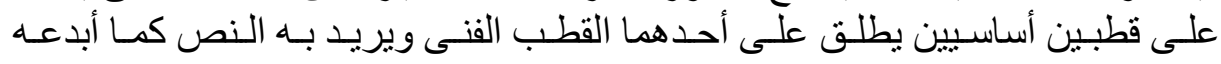

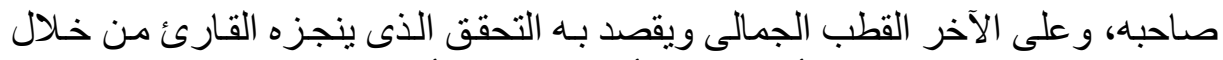

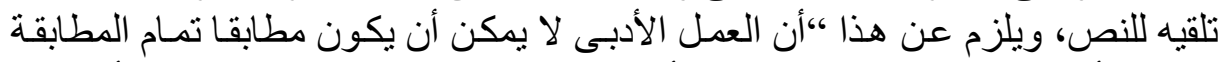

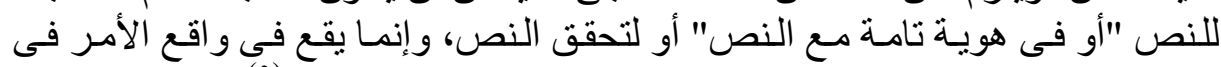

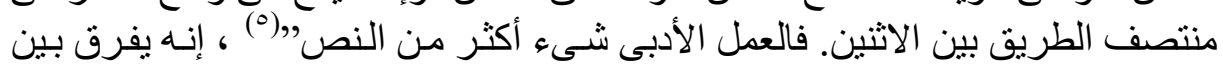




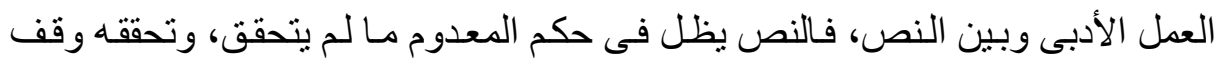

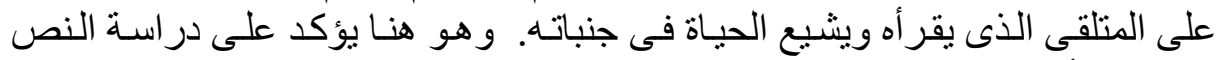

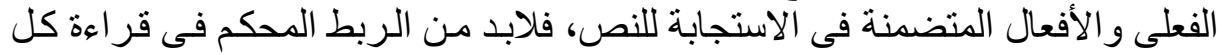

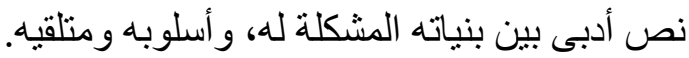

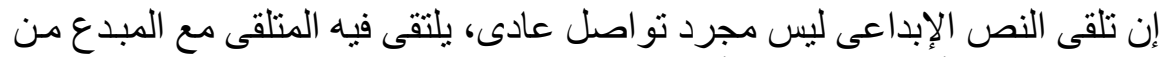

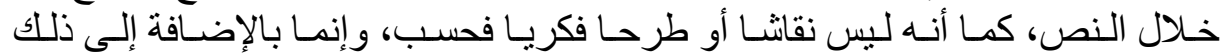

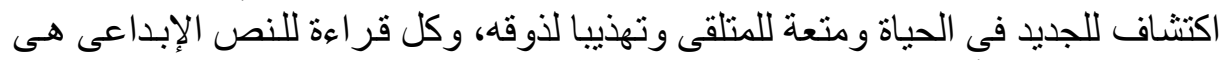

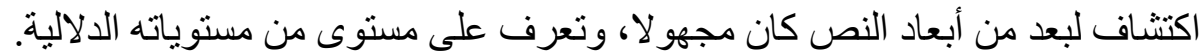

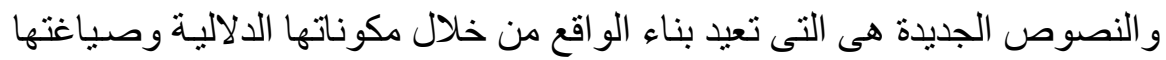

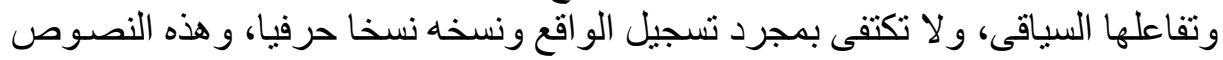

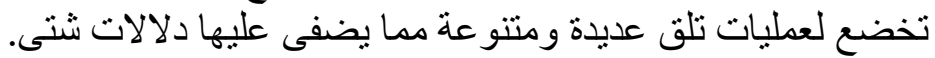

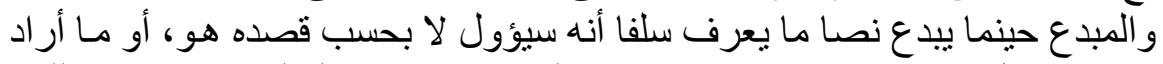

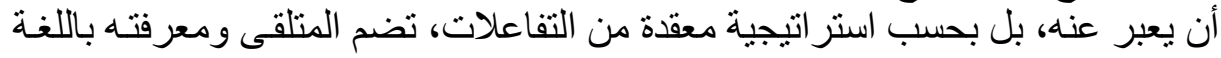

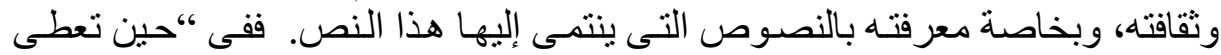

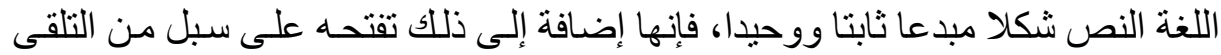

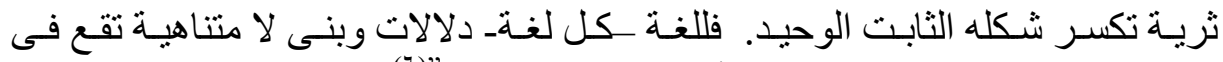

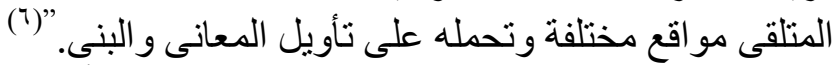

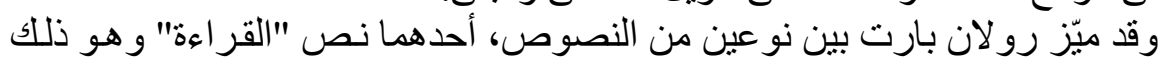

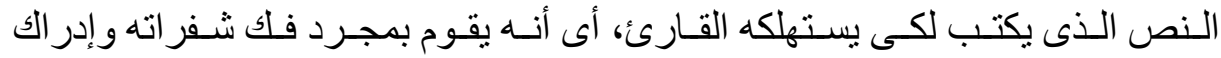

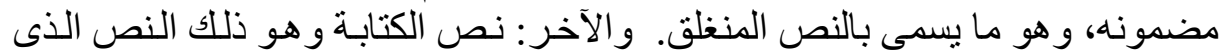

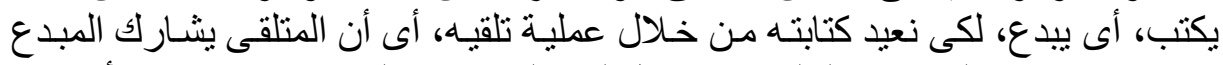

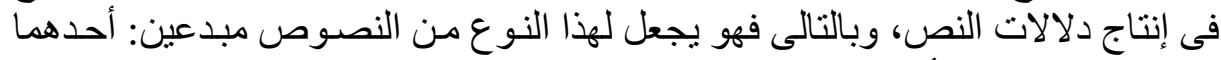

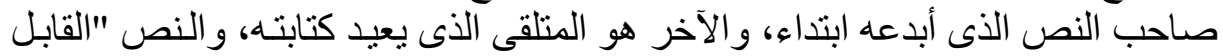

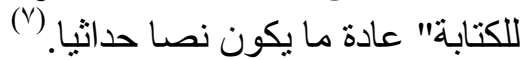

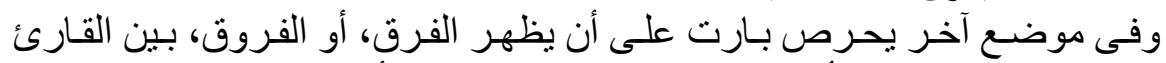

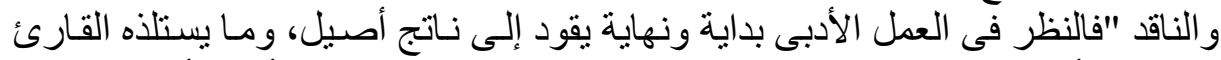

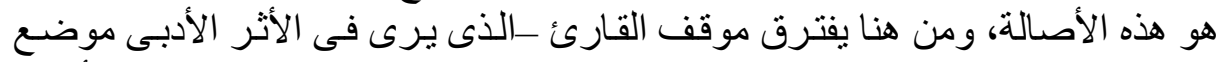

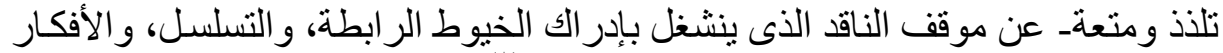

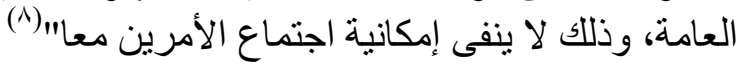




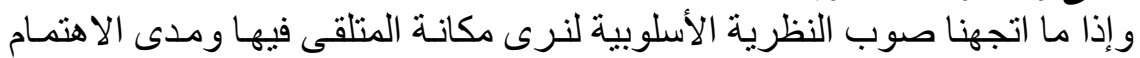

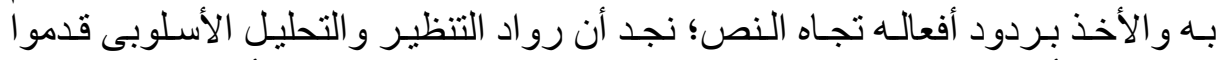

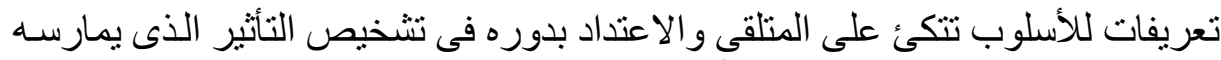
النص عليه داخل عملية التواصل على الأدبى.

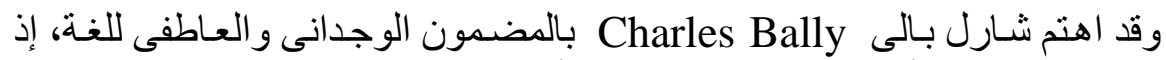

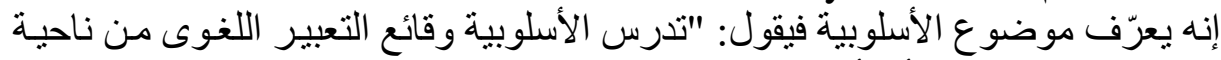

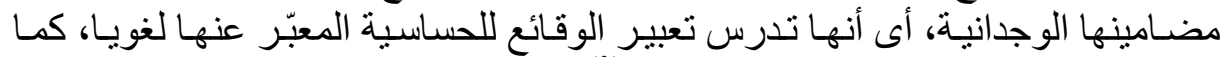

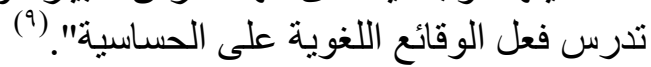

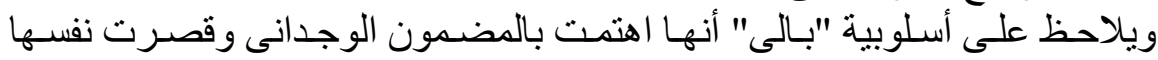

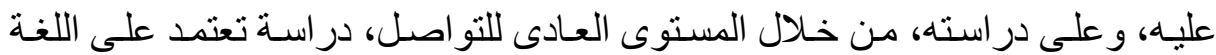

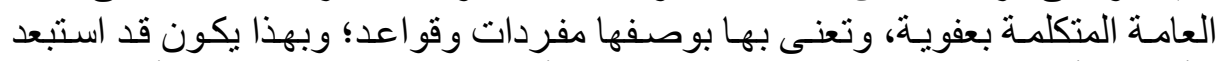

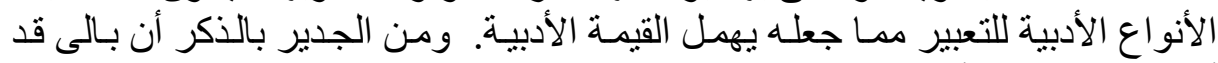

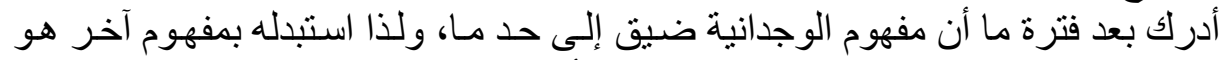

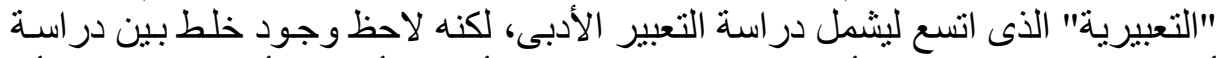

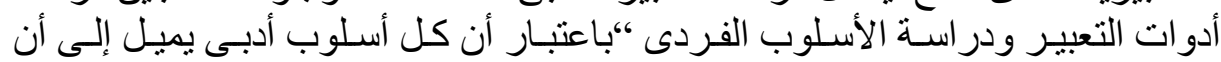

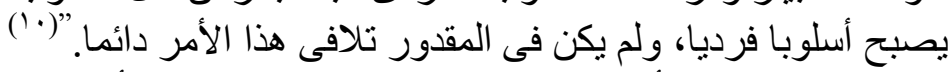

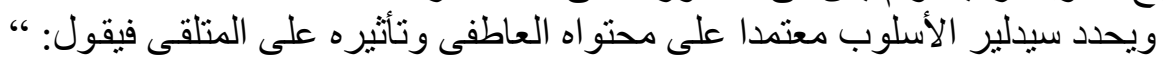

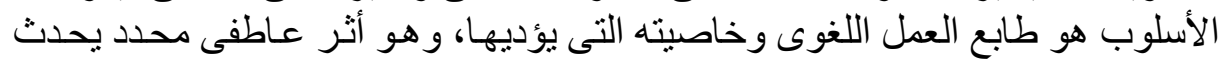

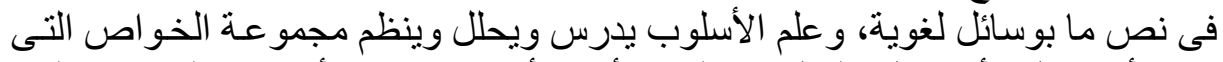

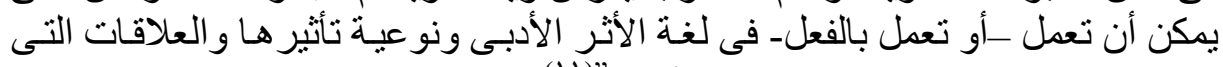

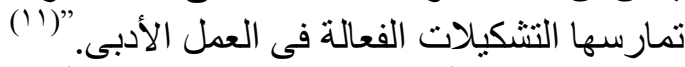

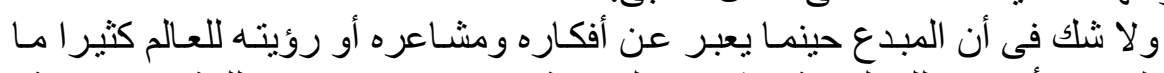

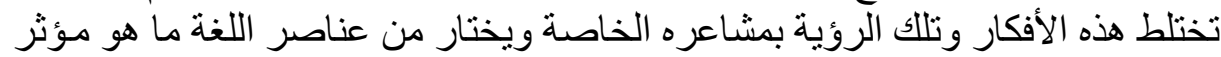

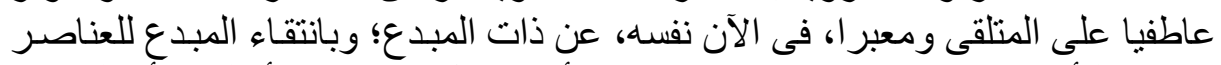

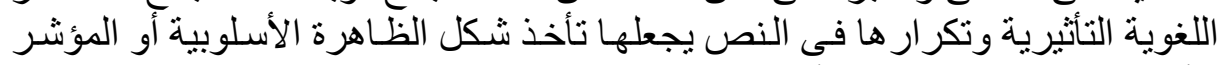

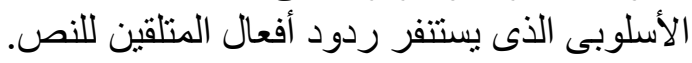

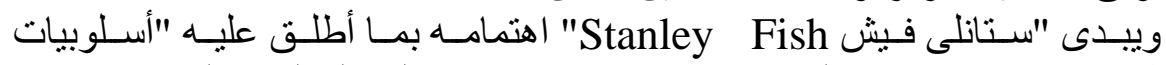

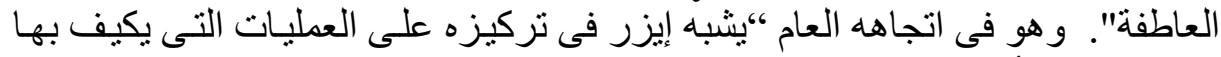

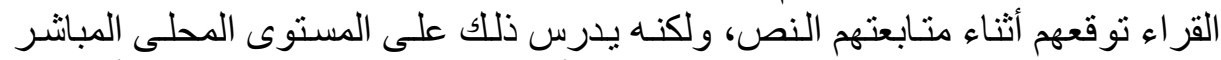

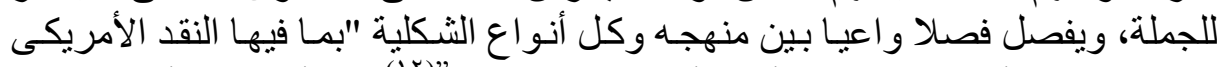

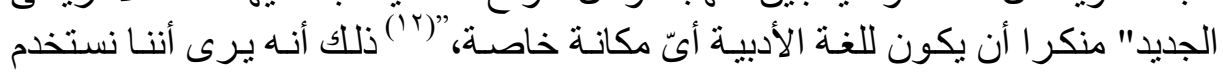




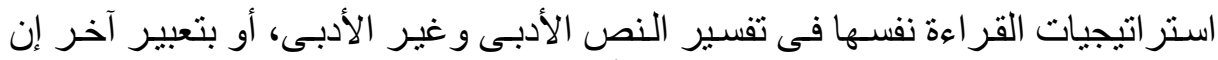

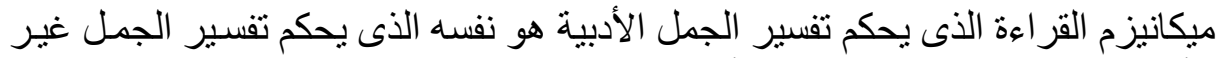

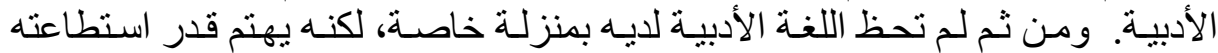

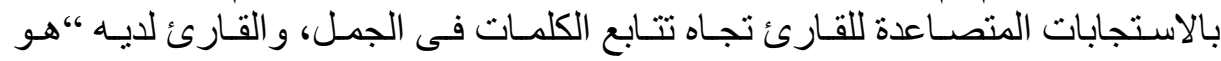

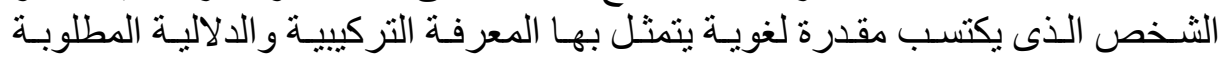

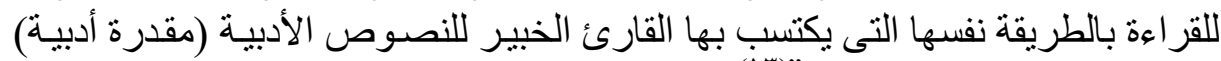

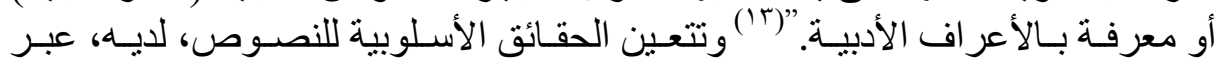

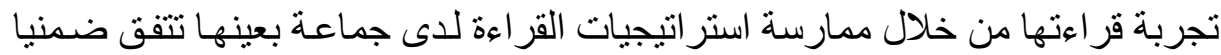

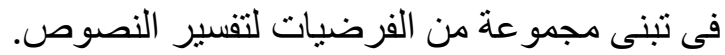

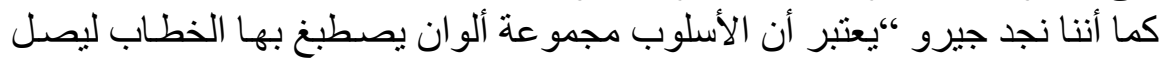

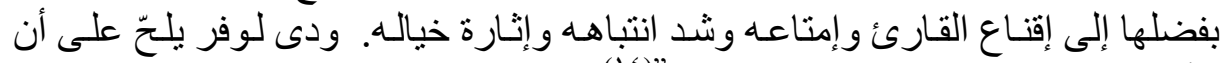

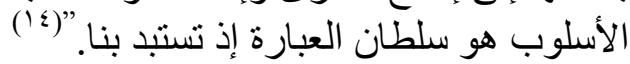

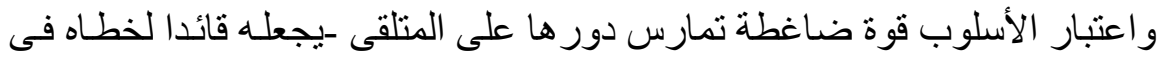

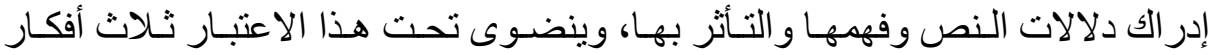

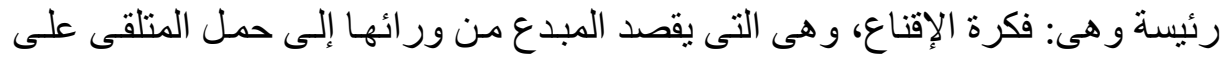

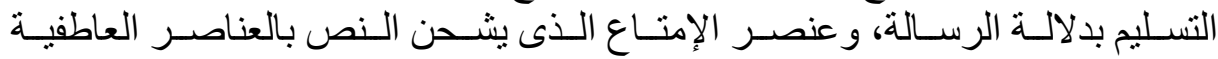

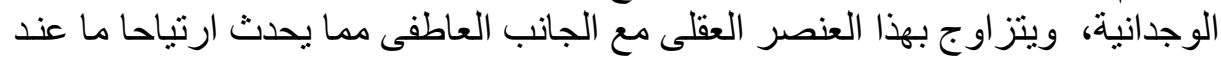

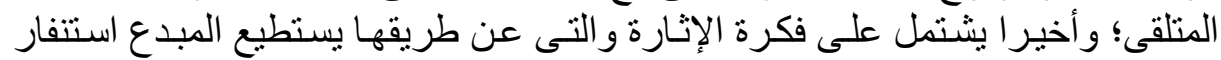

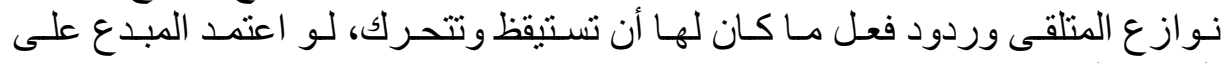

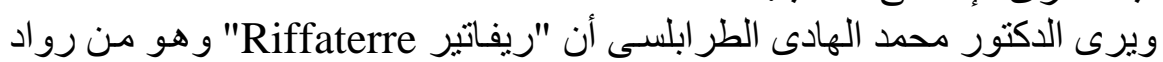

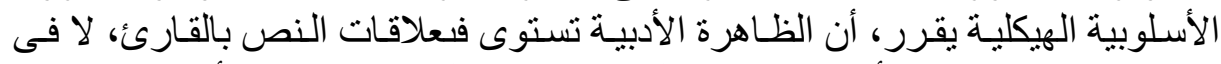

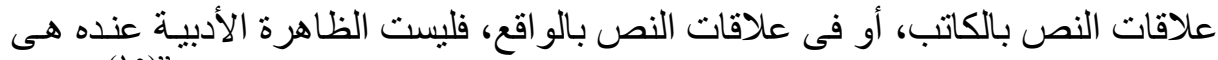

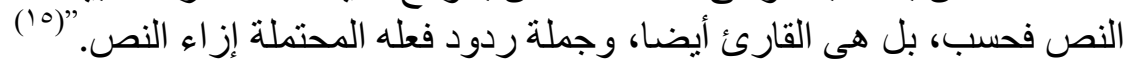

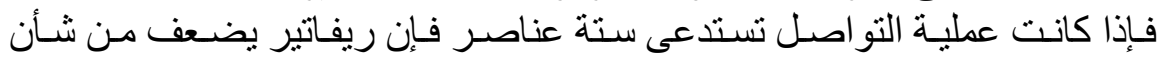

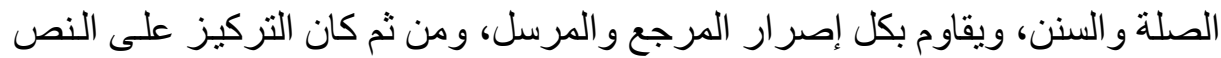

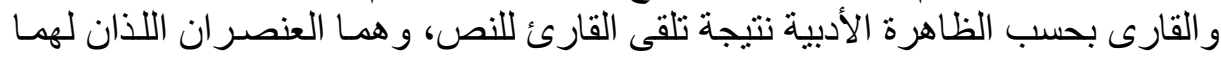
وجود مادى ملموس.

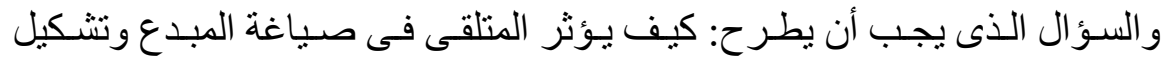

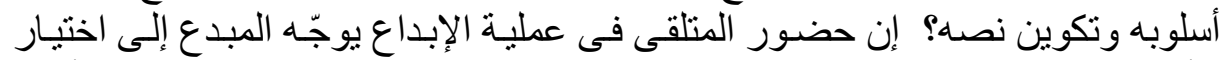

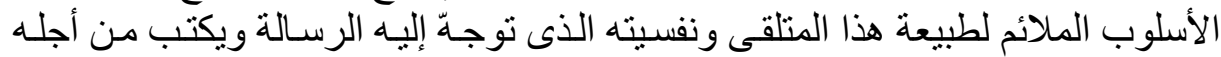

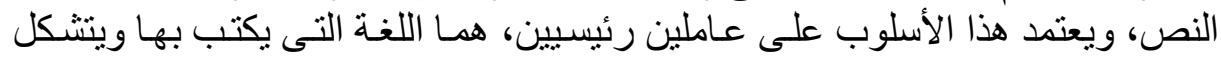




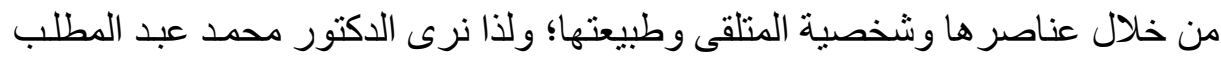

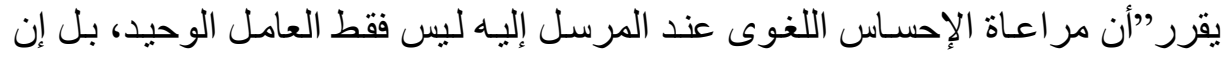

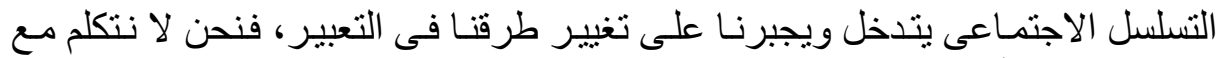

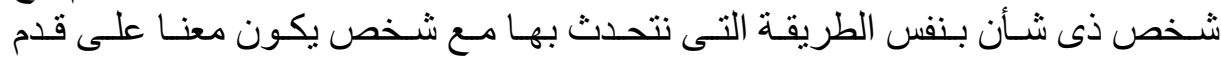

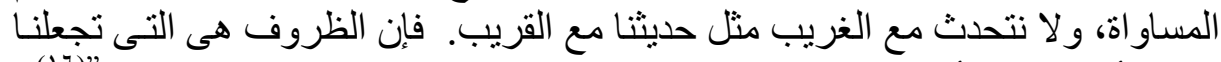

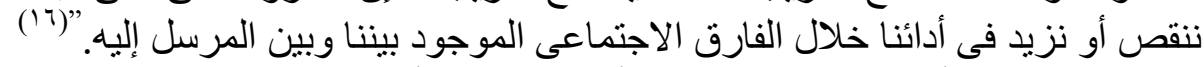

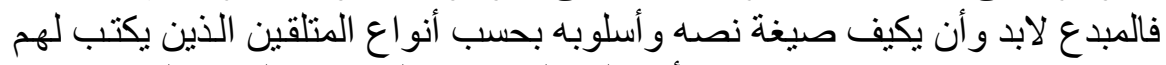

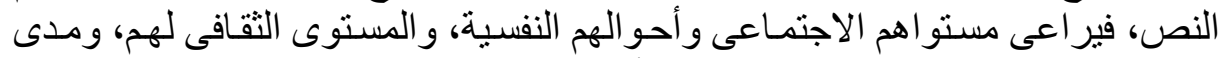

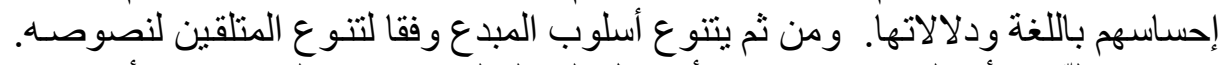

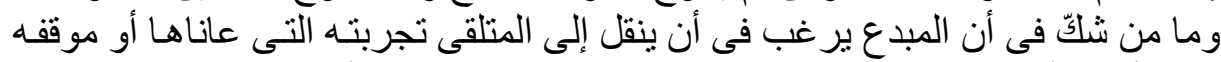

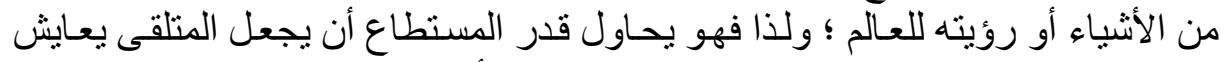

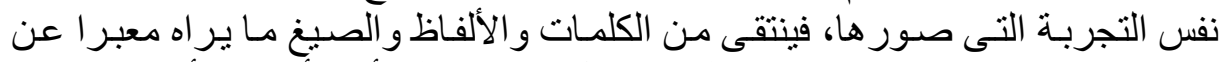

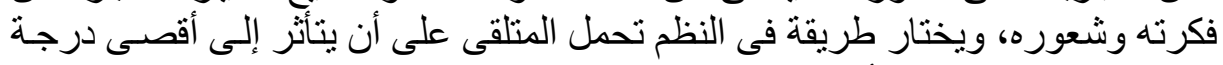

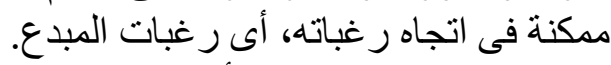

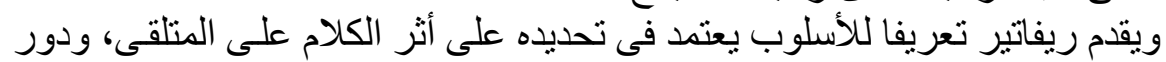

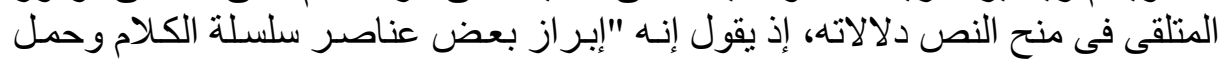

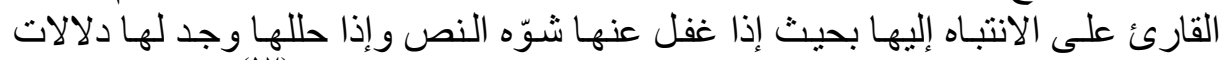

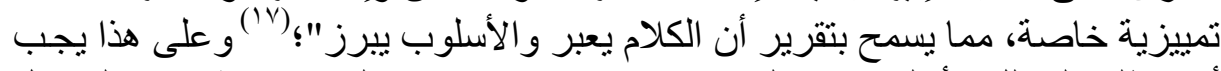

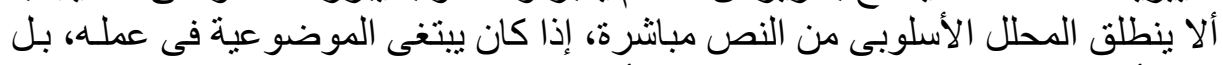

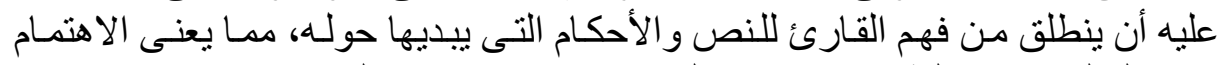

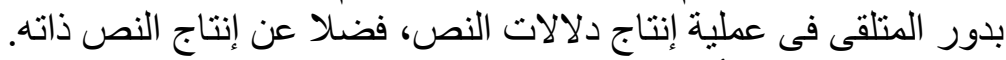

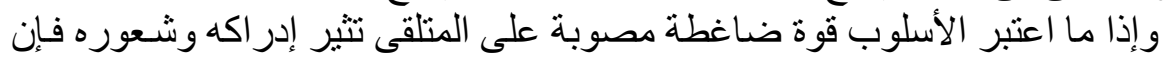

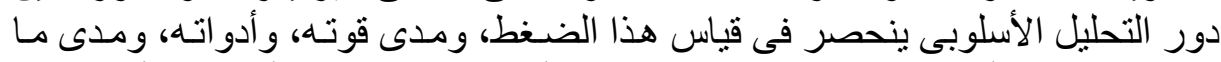

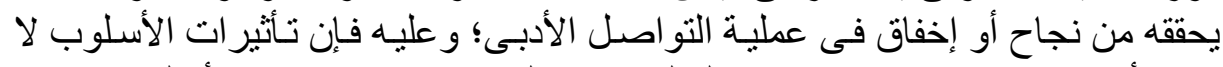

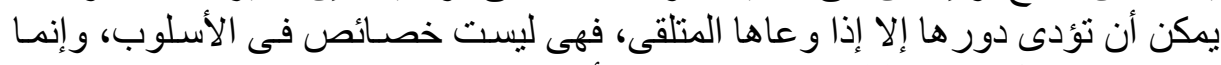

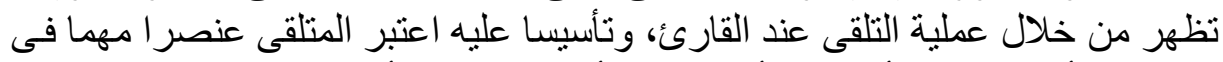

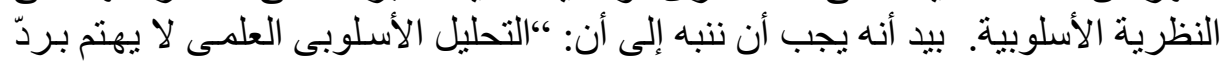

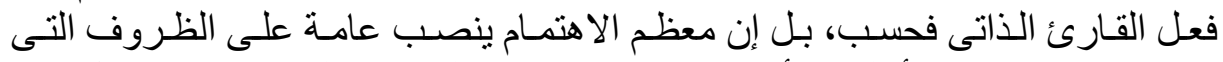

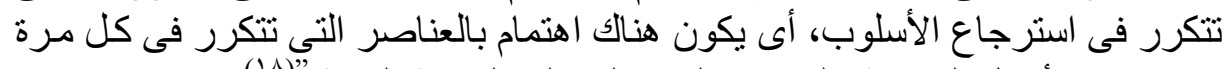

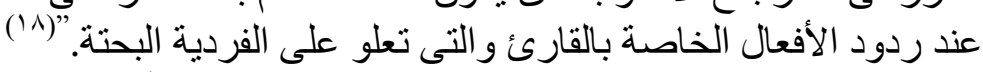

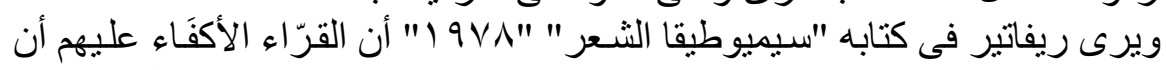

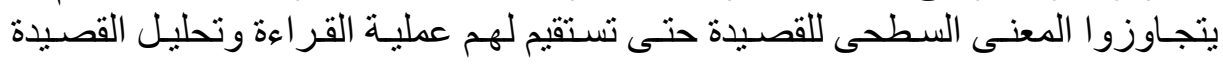




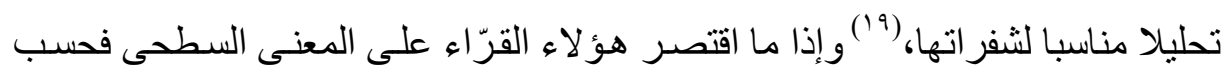

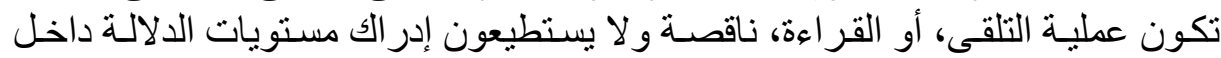

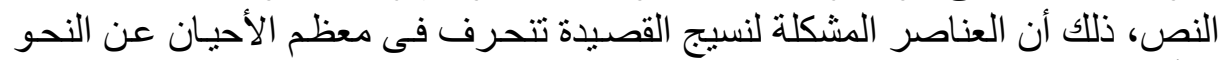

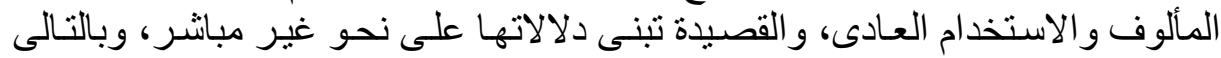

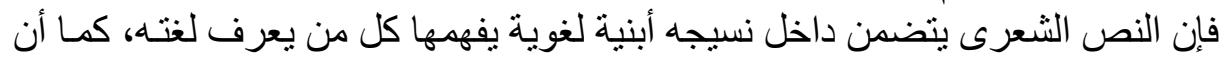

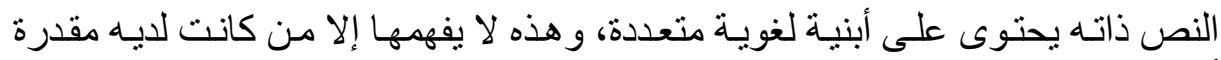

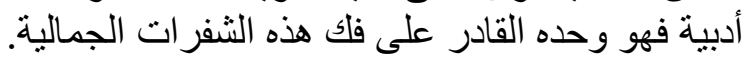

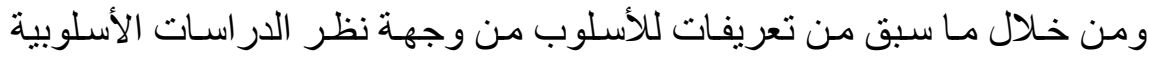

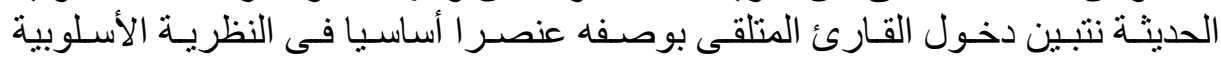

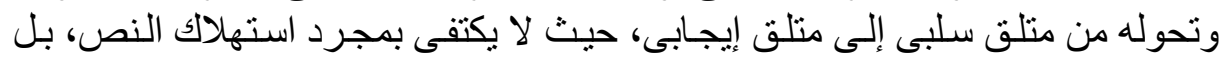

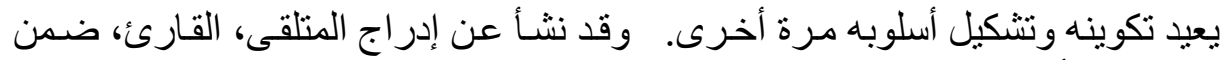

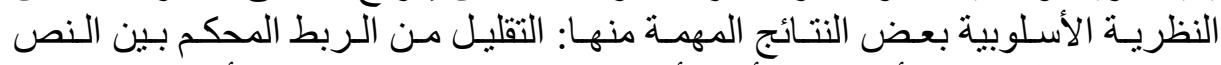

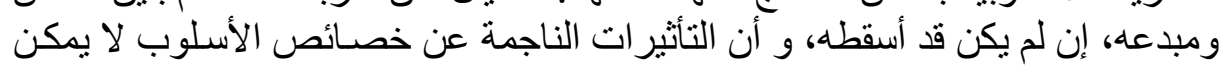

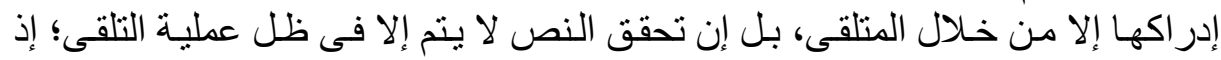

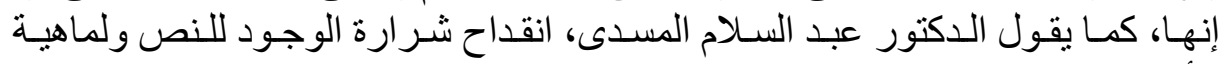

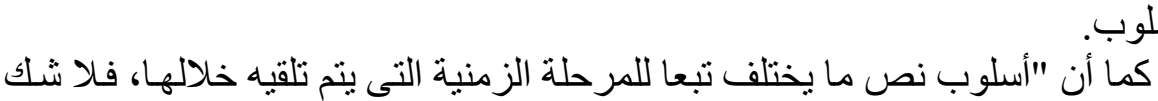

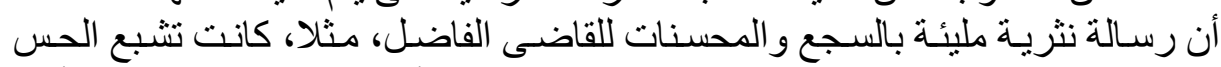

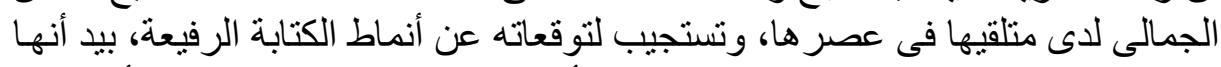

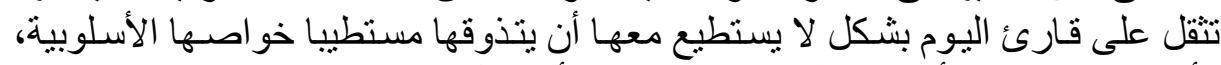

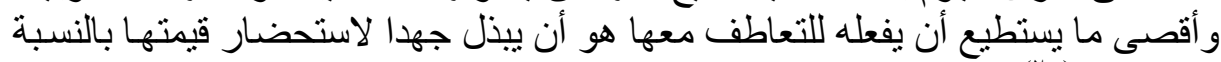

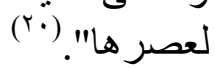

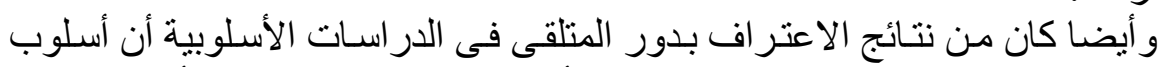

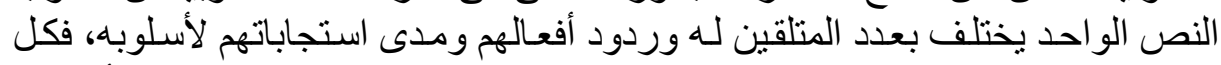

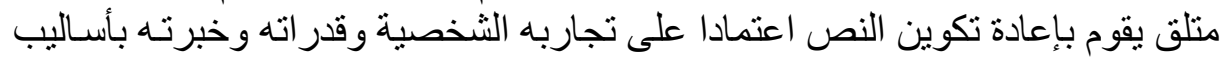

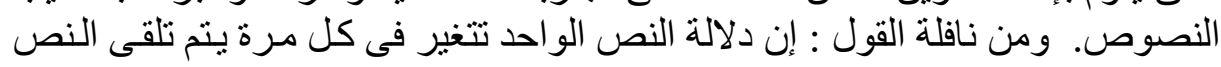

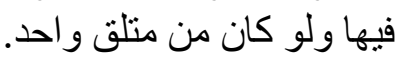

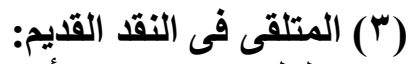

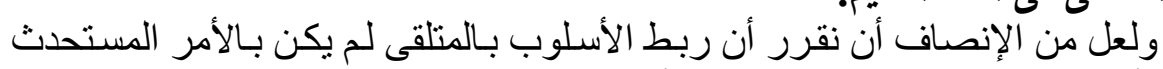

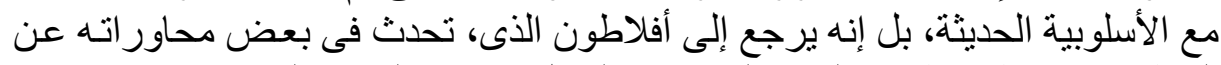

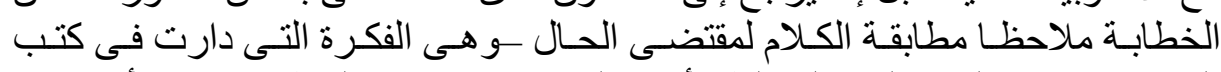

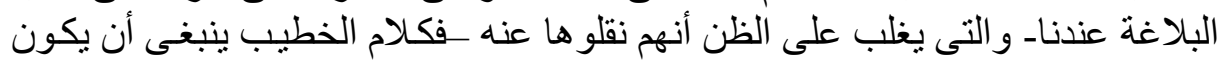




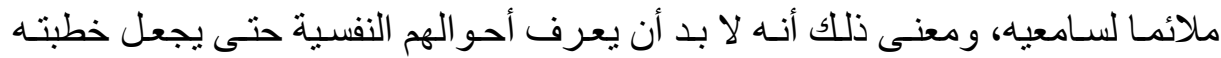

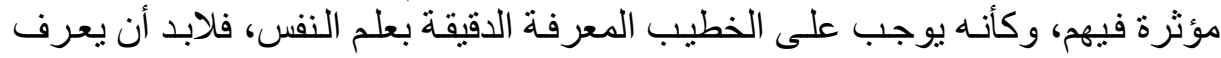

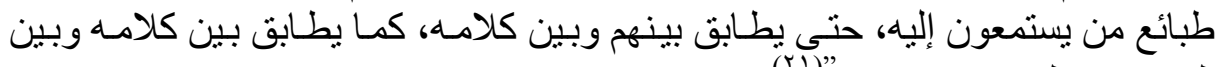

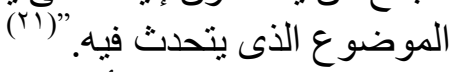

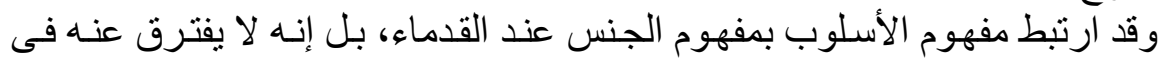

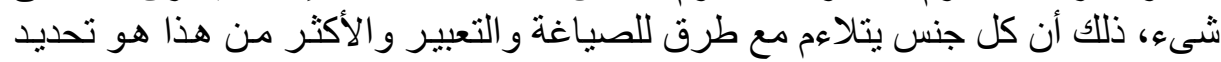

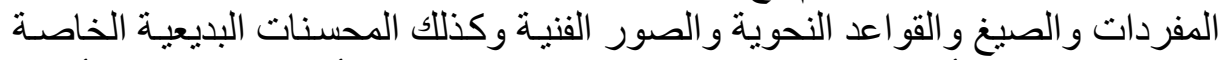

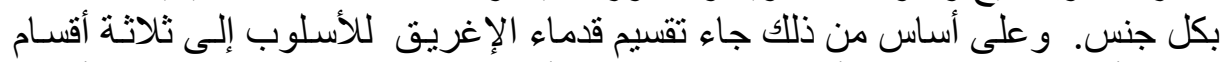

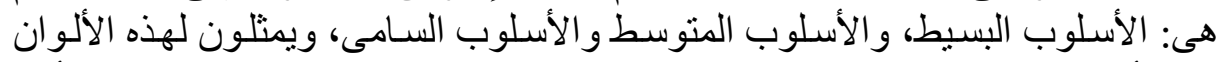

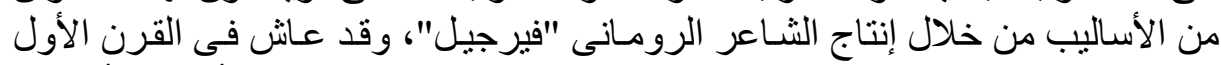

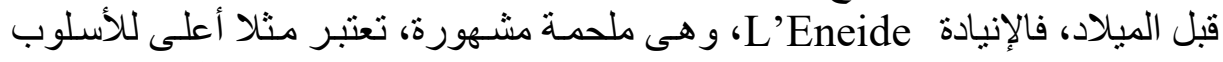

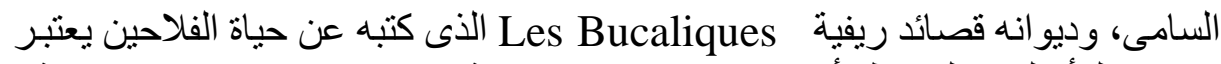

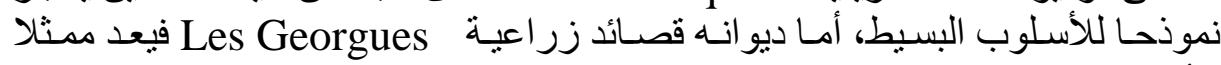

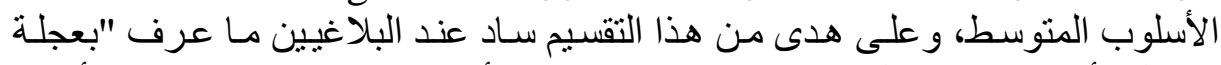

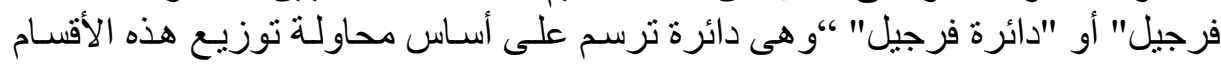

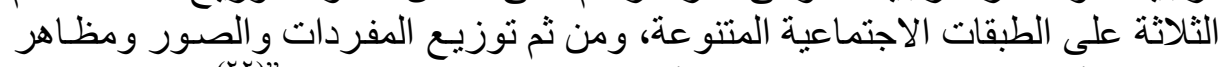

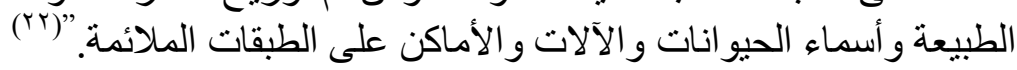

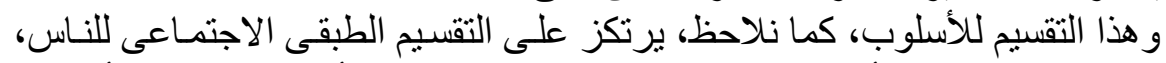

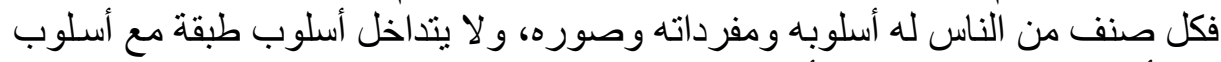

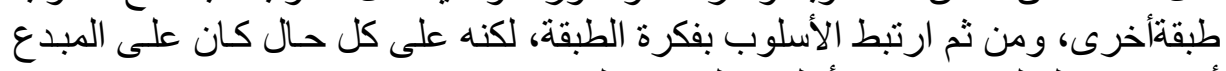

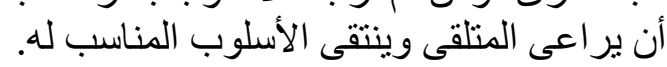

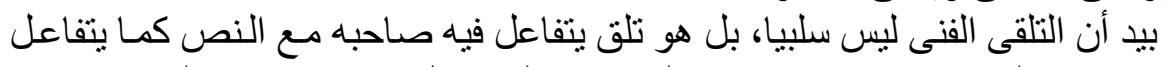

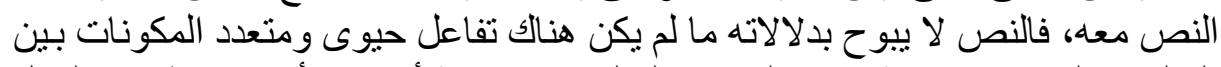

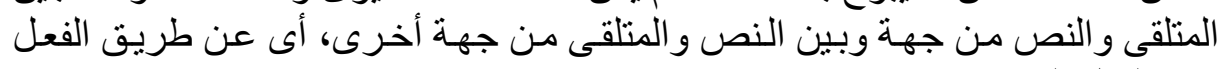
ورد الفعل الذى يصير بدوره فئن فينا.

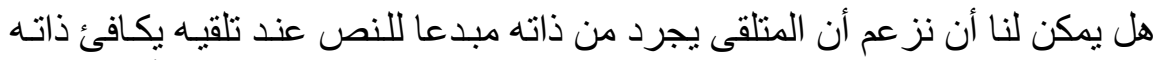

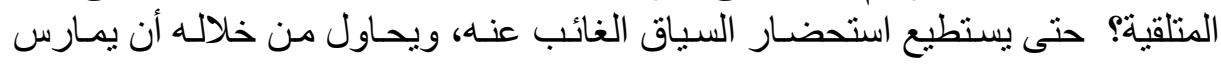

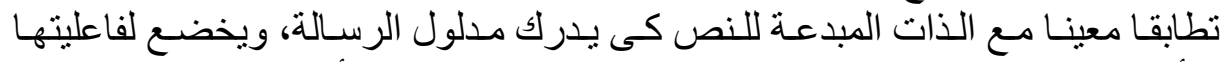

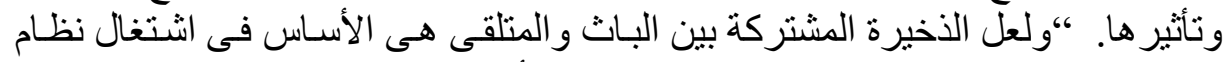

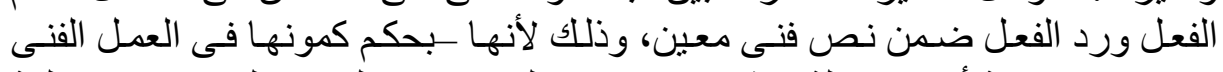

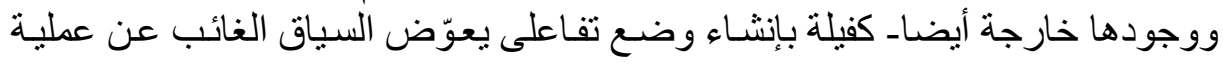


التو اصل، ويضمن نو عا من التطابق بين الفاعلية التى ير غب فيها المصدر و الاستجابة

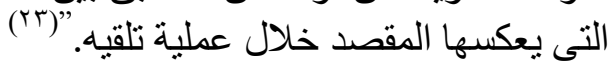

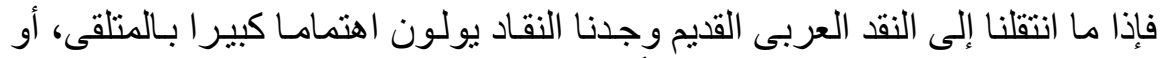

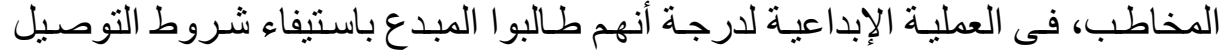

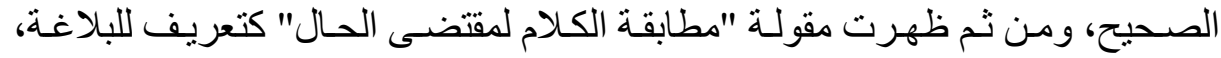

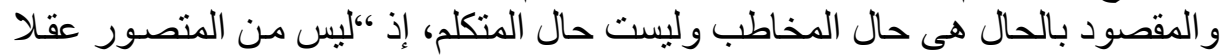

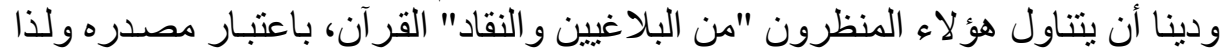

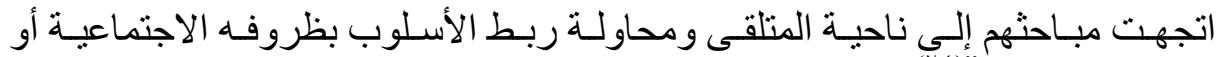

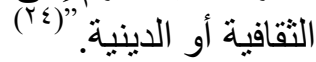

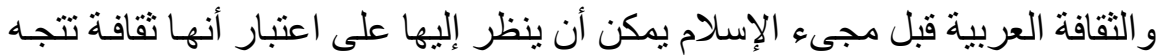

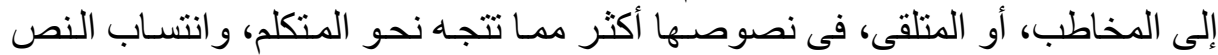

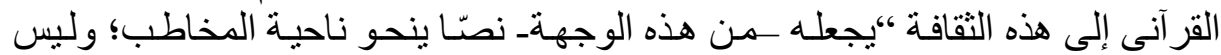

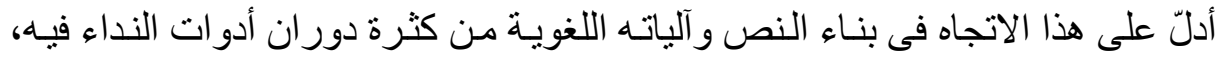

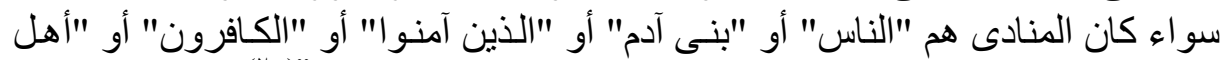

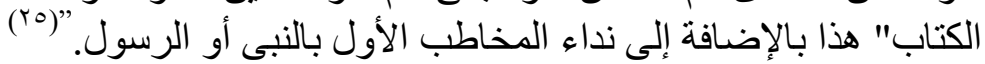

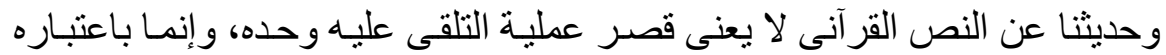

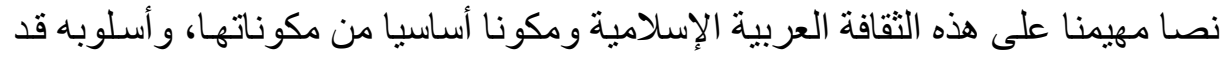

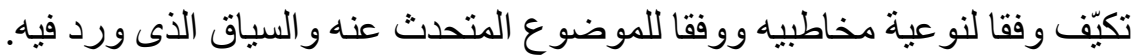

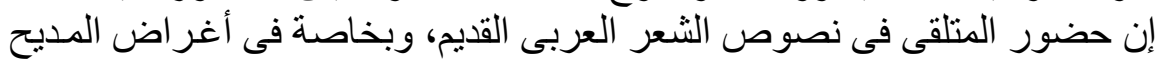

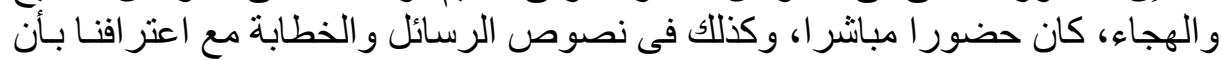

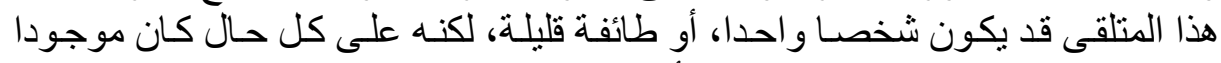

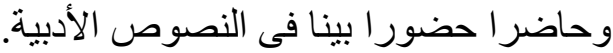

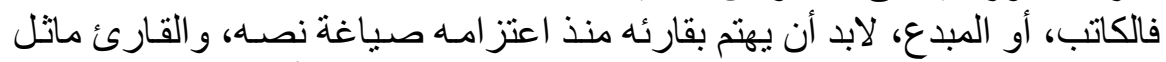

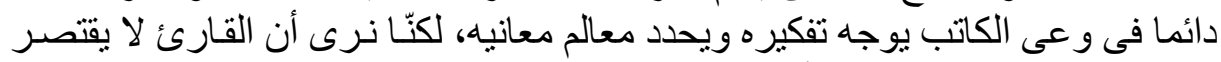

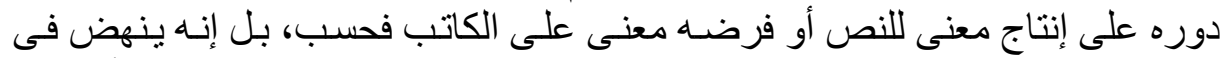

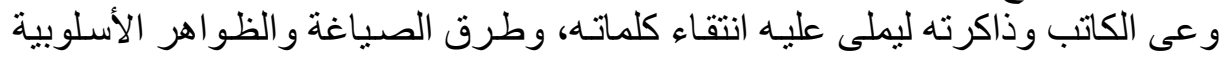

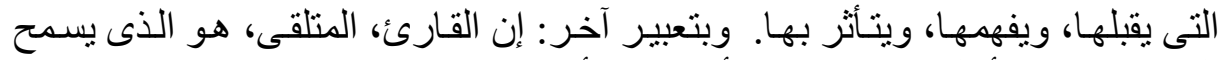

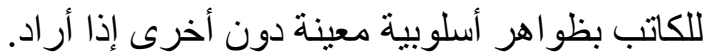

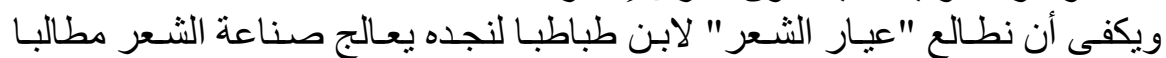

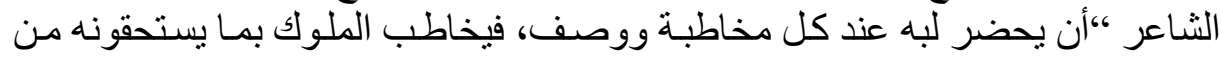

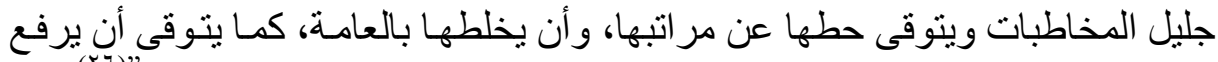

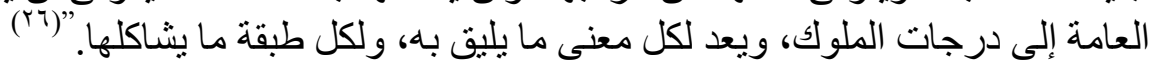




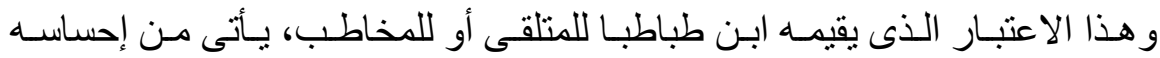

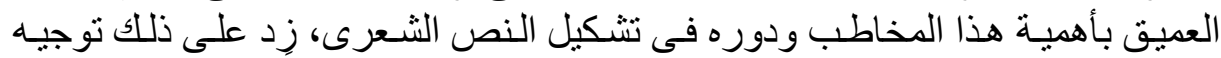

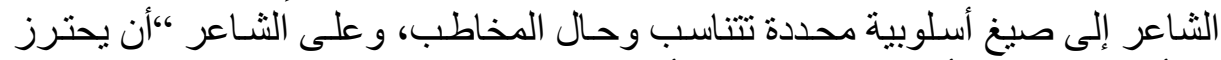

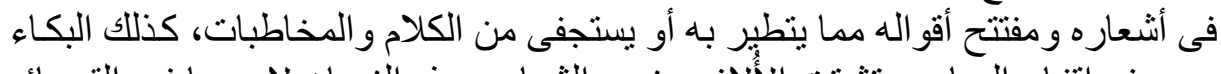

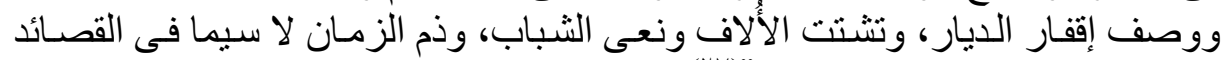

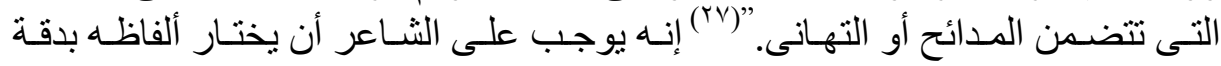

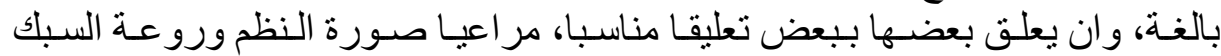

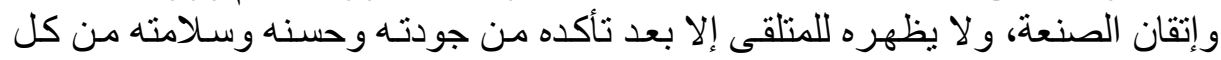

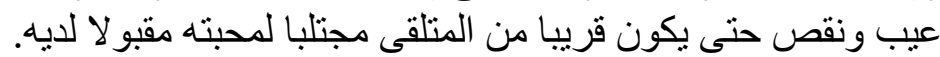

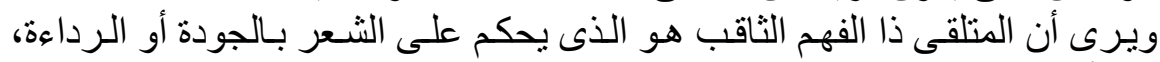

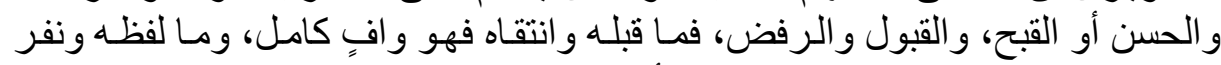

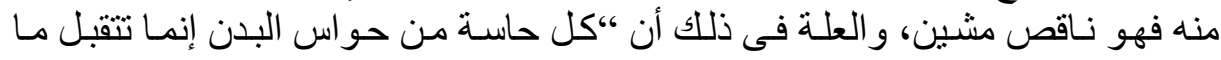

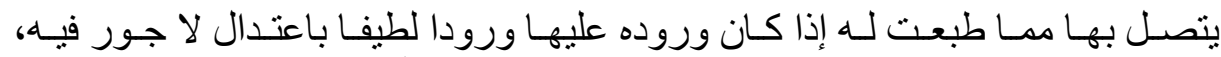

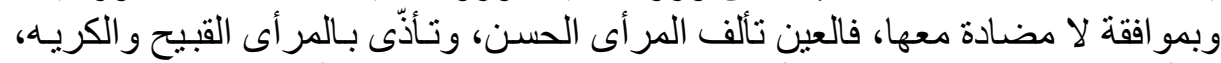

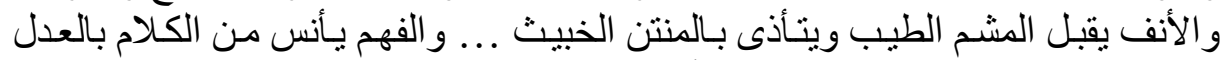

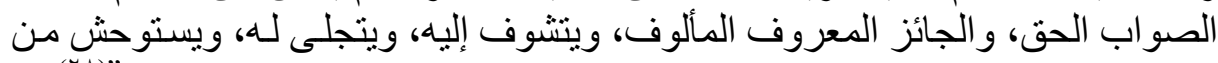

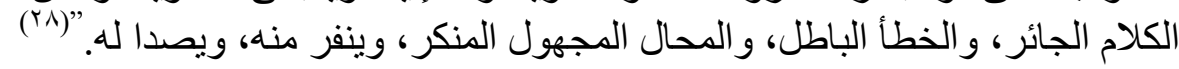

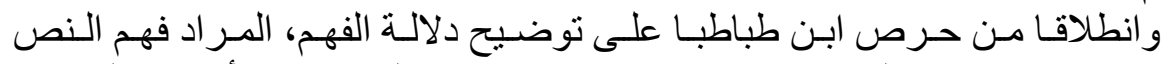

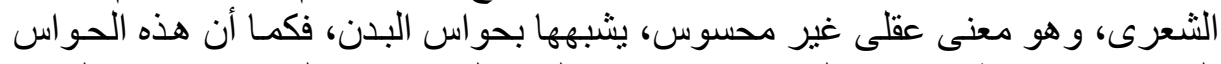

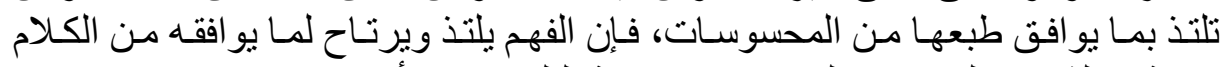

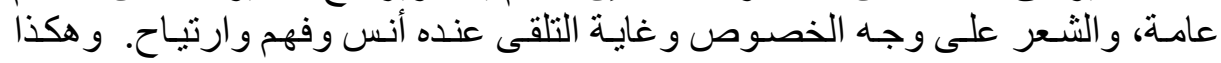

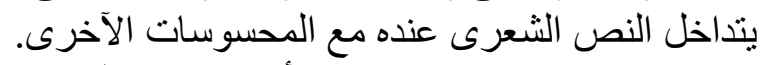

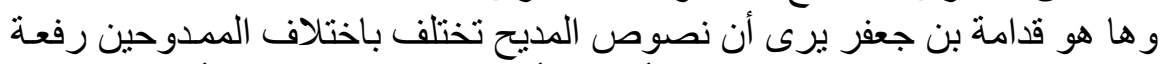

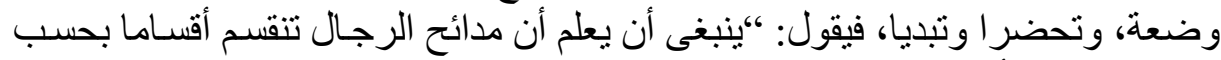

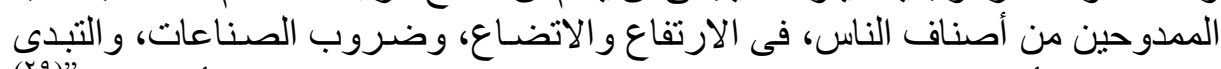

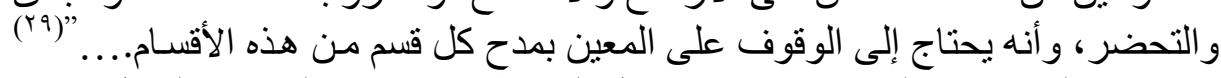

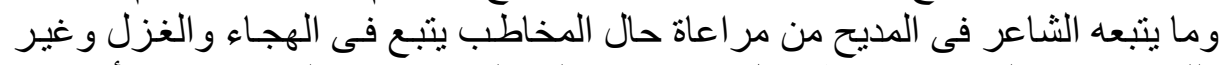

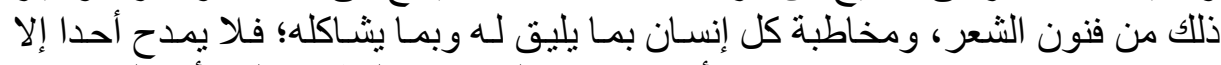

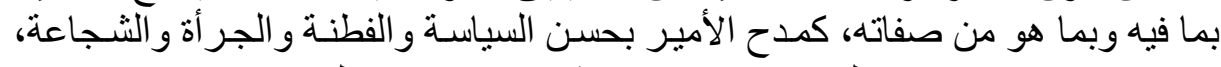

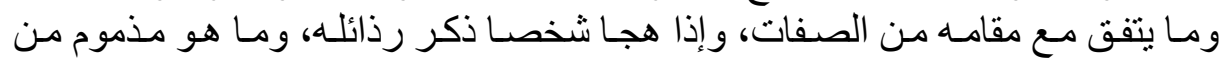

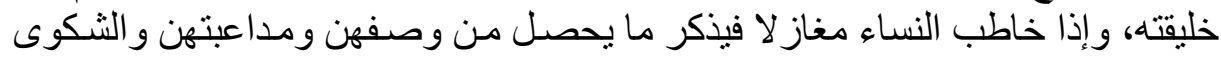

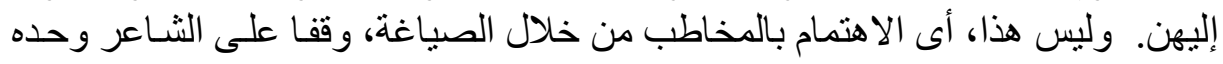




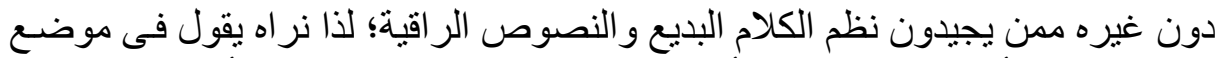

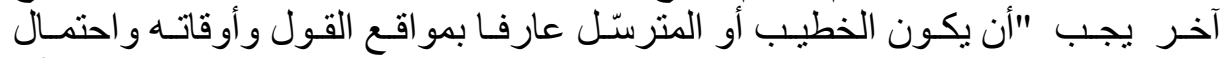

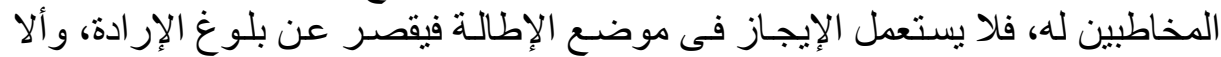

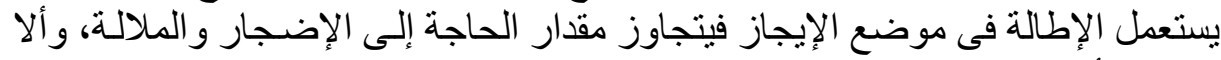

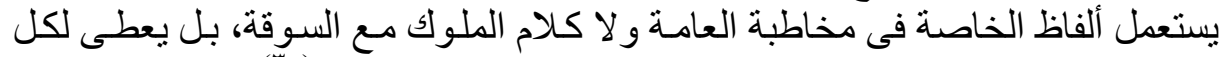

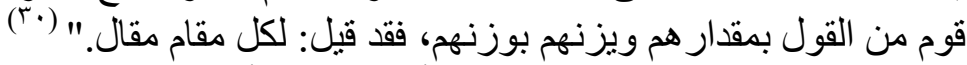

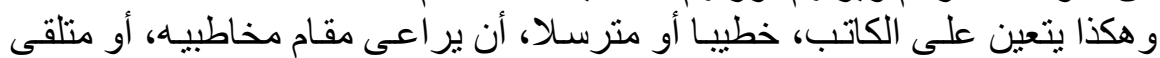

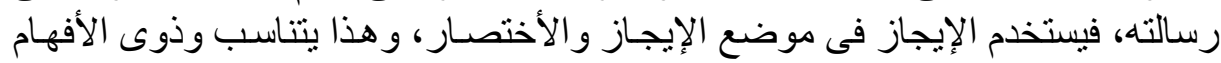

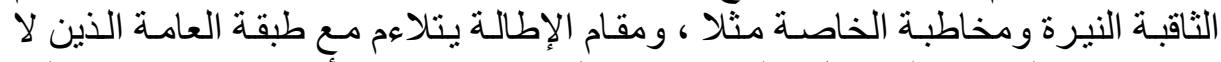

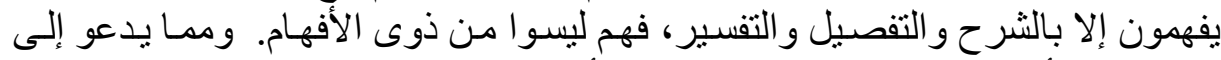

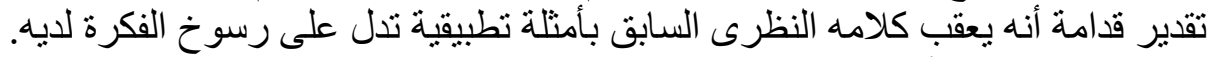

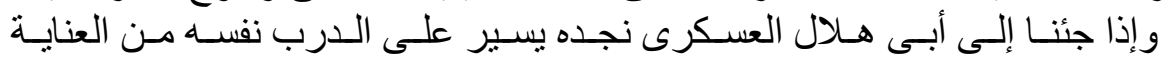

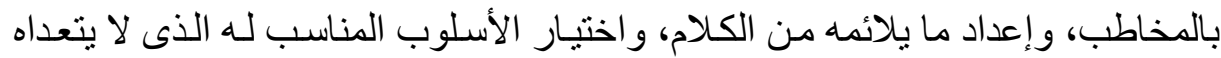

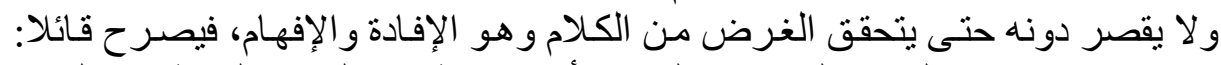

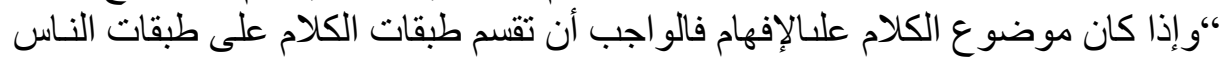

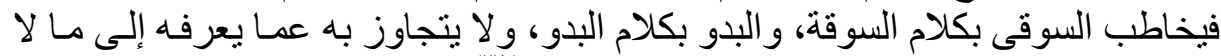

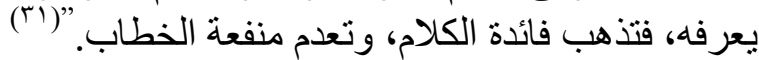

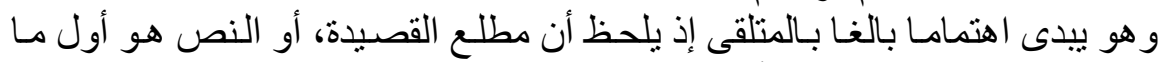

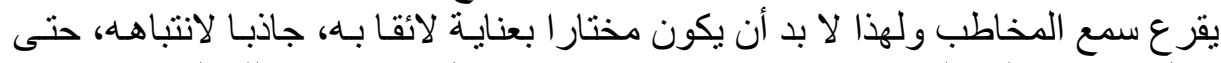

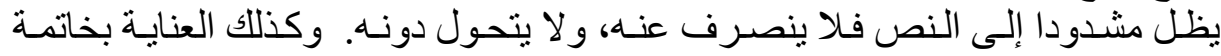

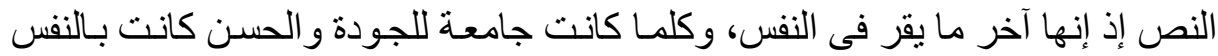

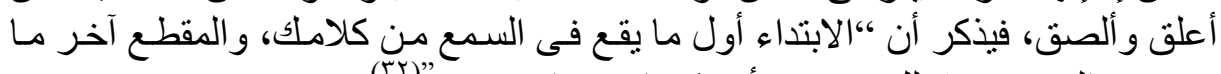

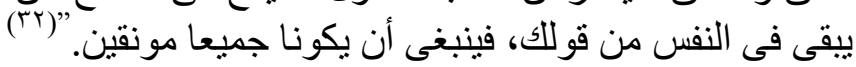

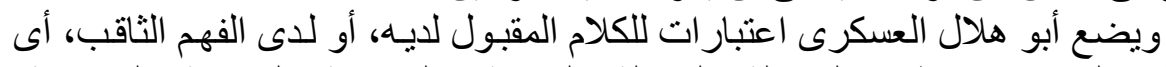

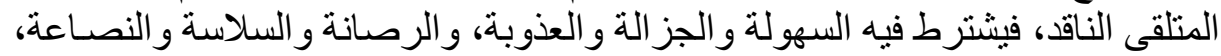

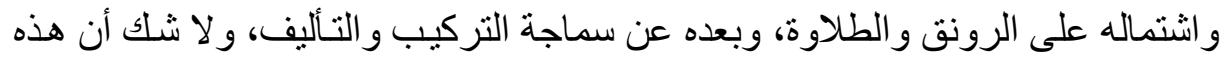

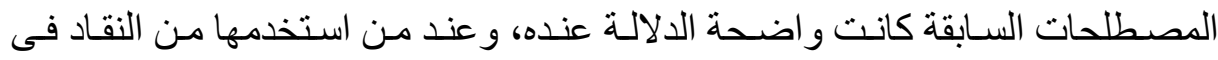
عصره و إن لم تكن دلالتها بيّنة عندنا الآن.

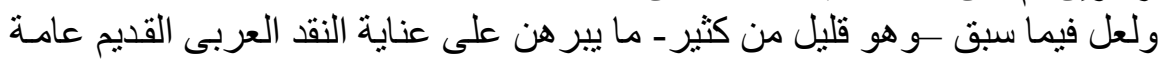

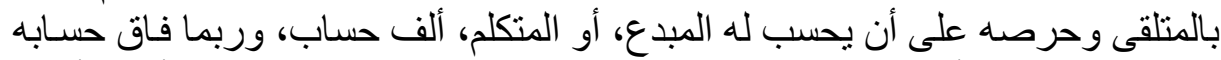

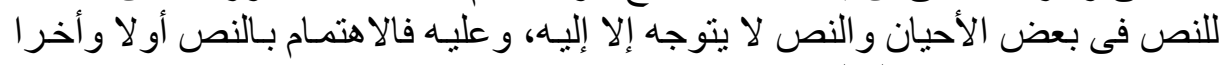
هو اهتمام غير مباشر بالمتلقى. بانى 


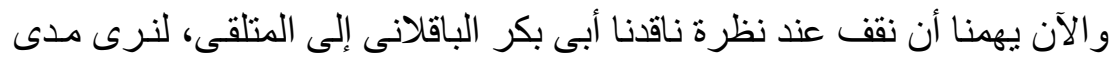

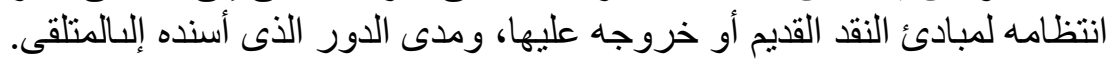
( ) ( المتلقى عند الباقلانى:

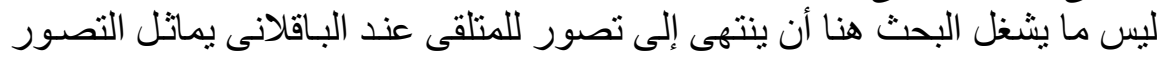

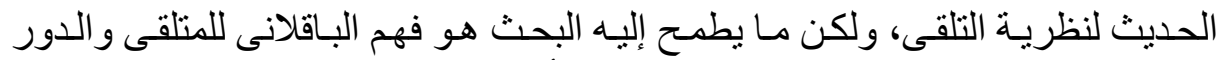

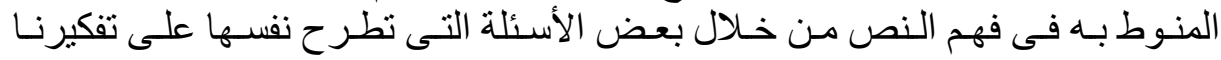
الر الهن.

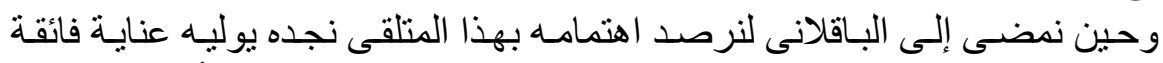

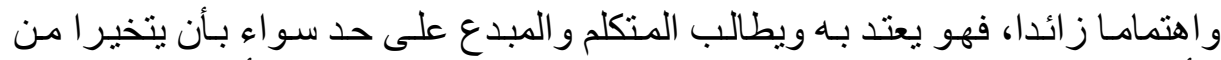

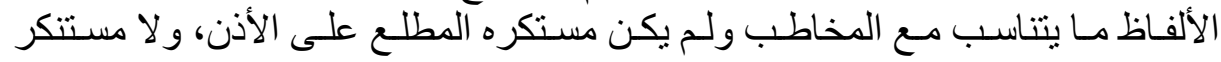

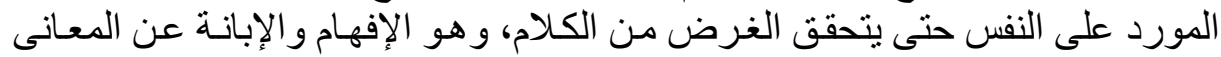

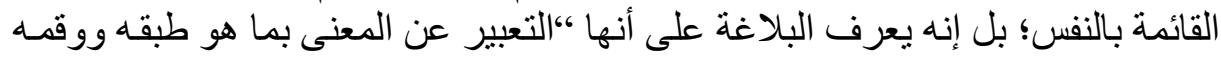

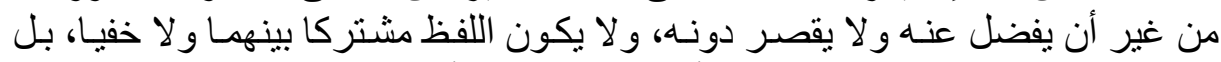

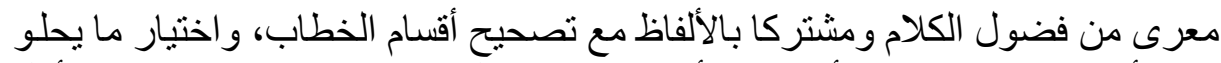

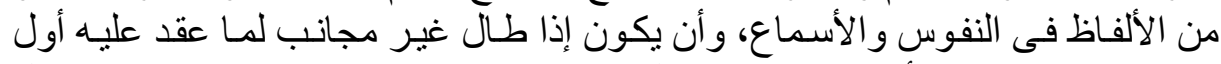

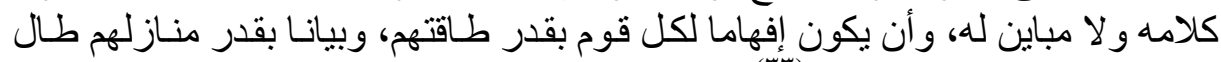

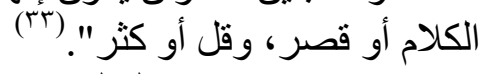

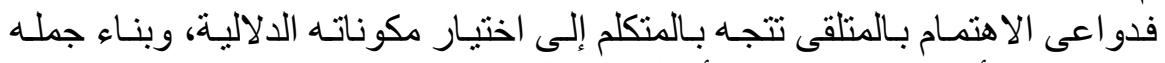

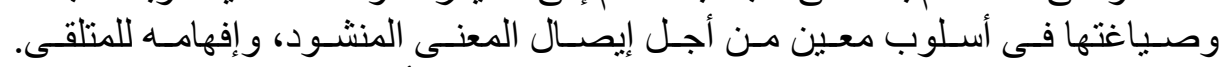

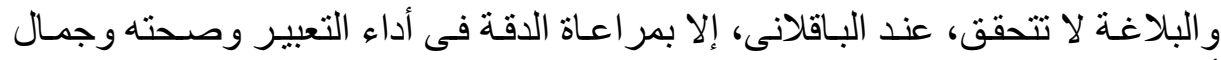

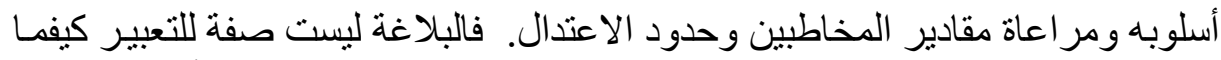

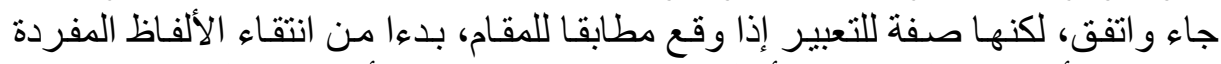

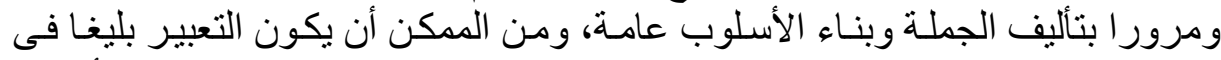

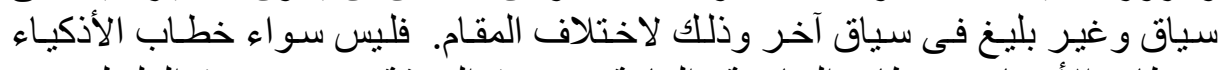

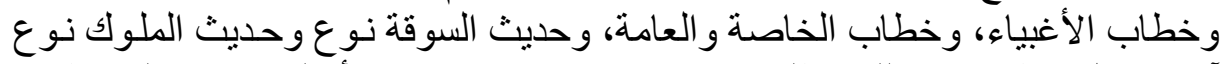

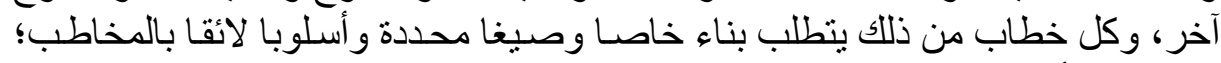

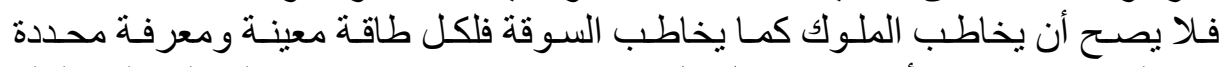

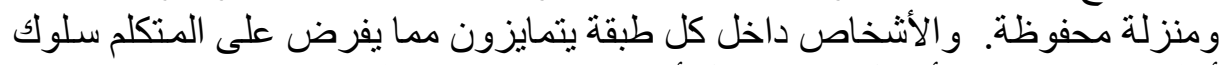

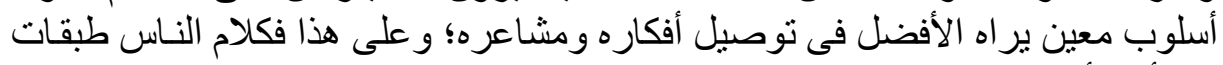

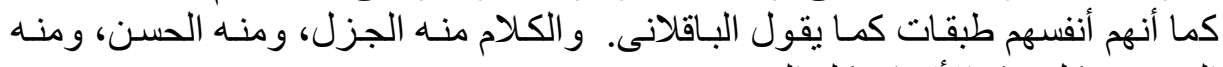
القبيح، وبكل هذه الأقسام تكلم العرب. 


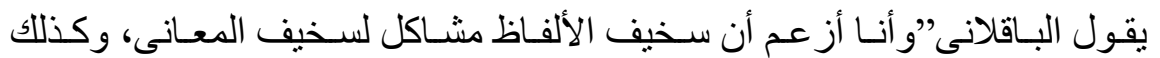

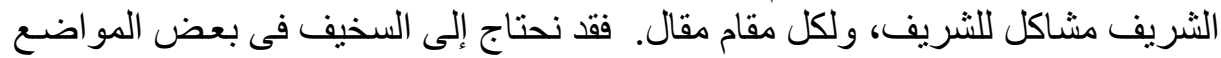

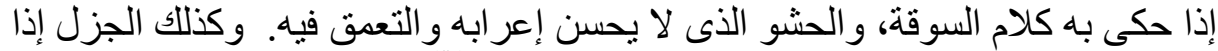

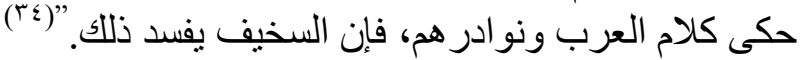

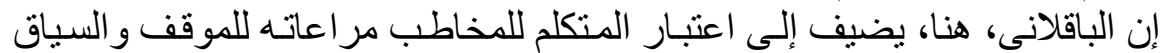

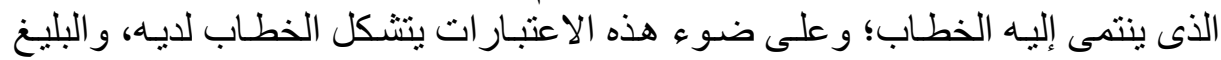

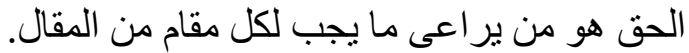

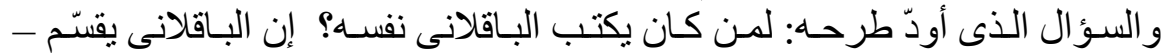

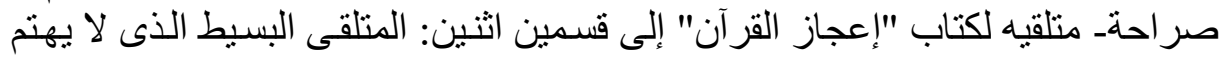

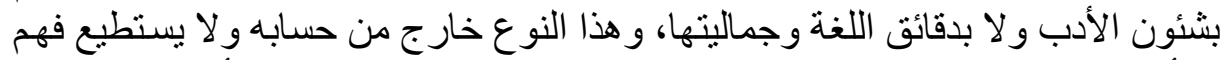

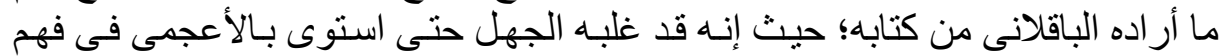

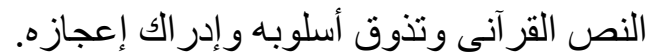

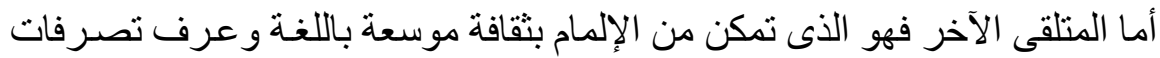

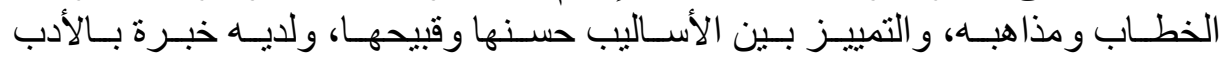

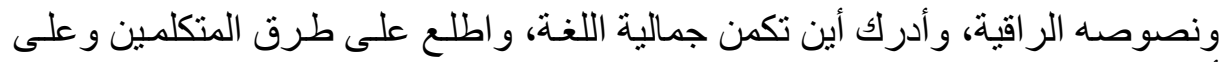

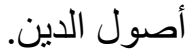

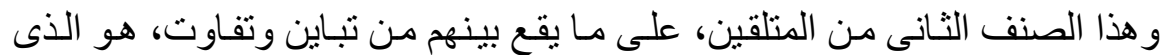

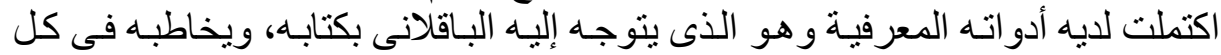

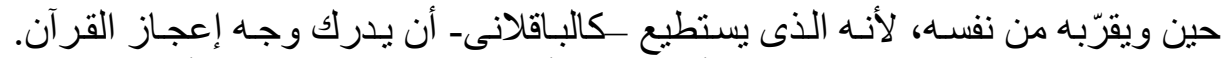

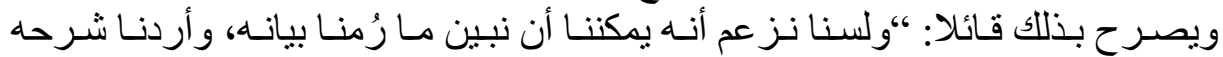

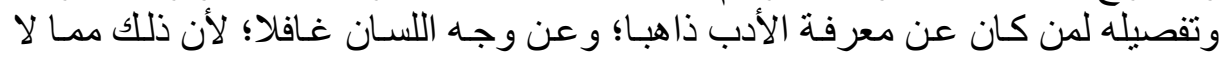

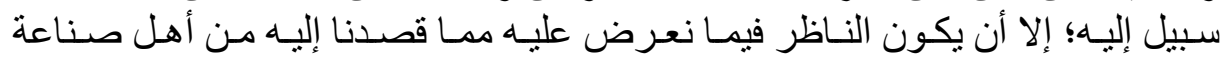

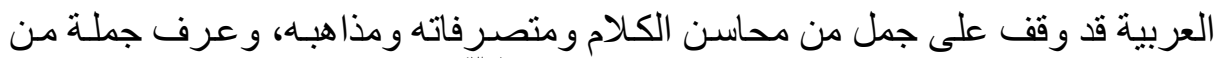

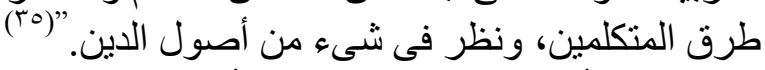

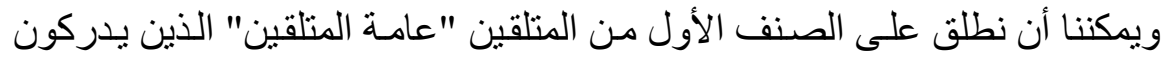

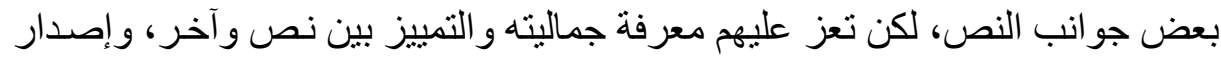

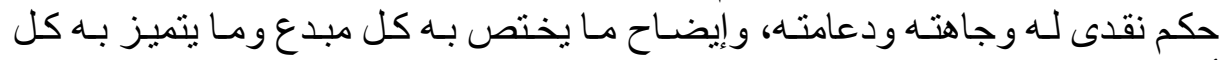

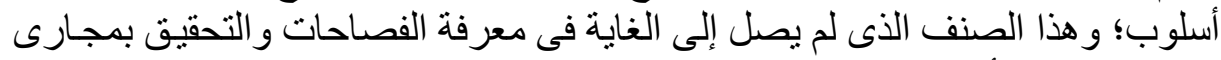

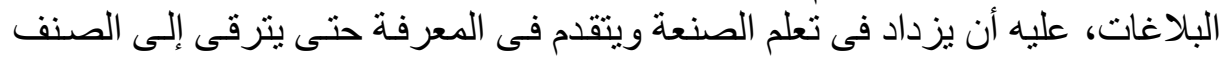

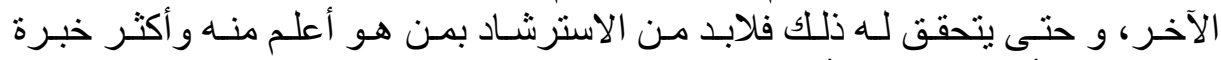
بالنصوص و أساليبها وشتى أنواع المعرفة. 


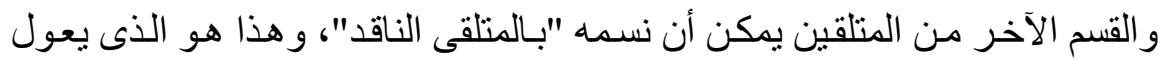

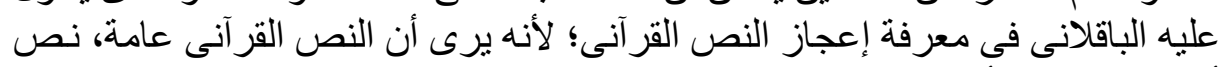

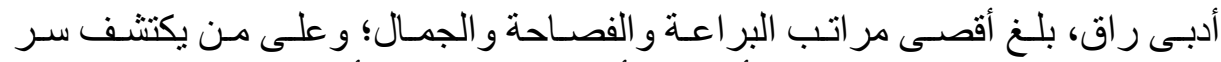

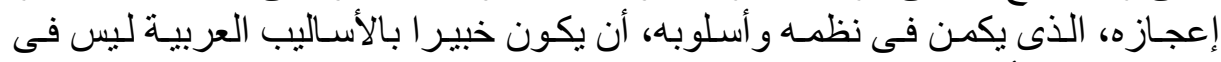

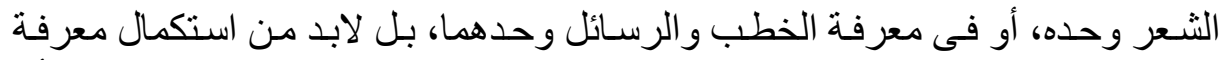

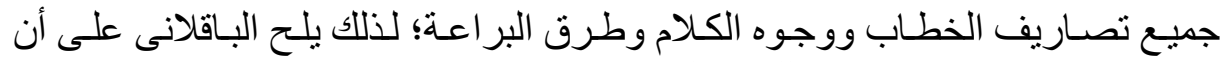

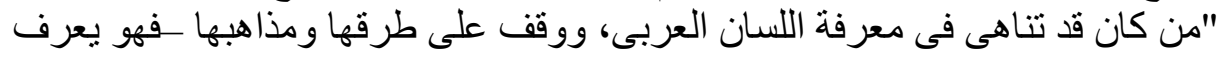

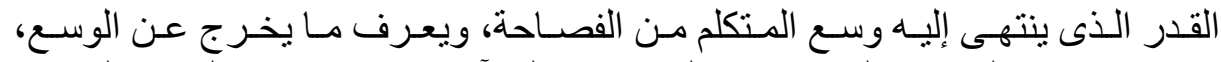

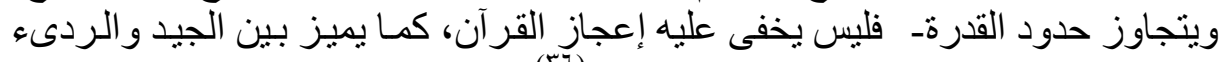

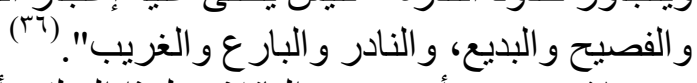

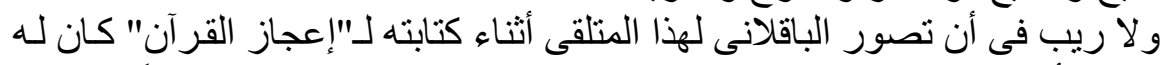

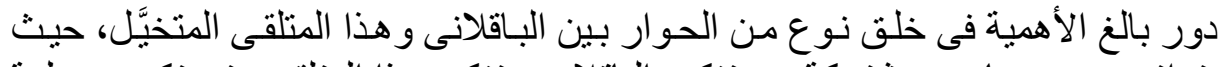

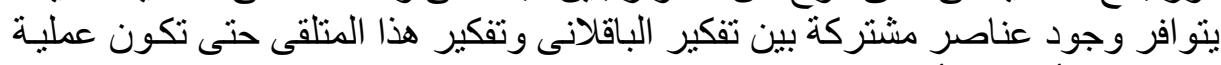

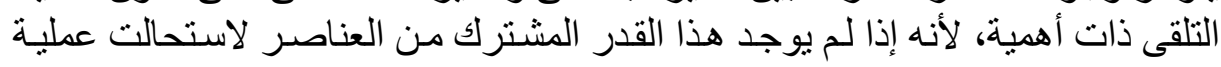

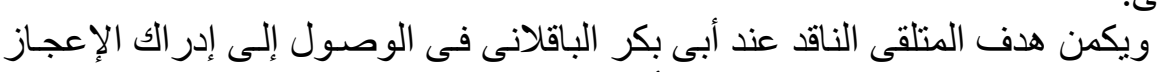

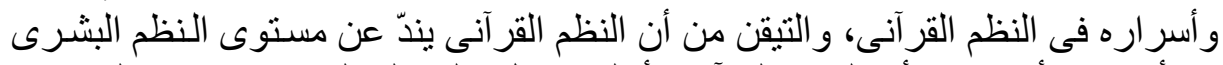

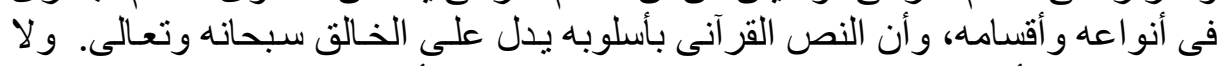

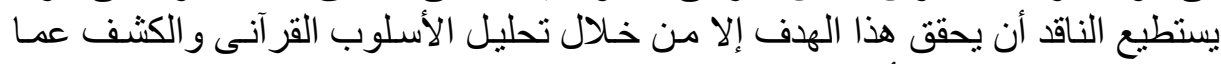

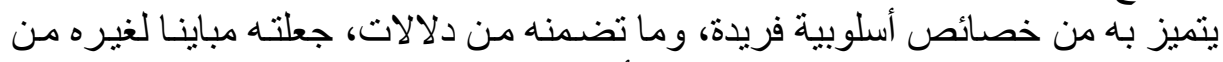

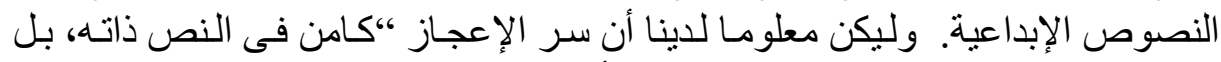

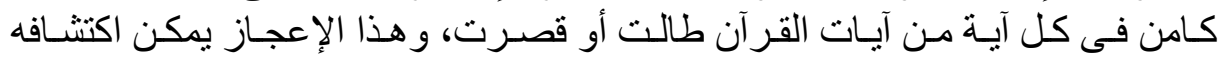

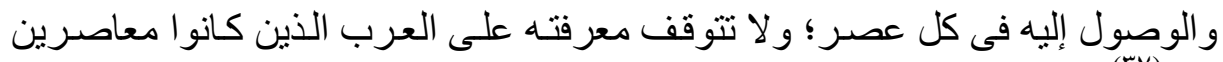
(एv) له

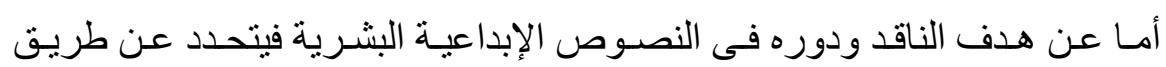

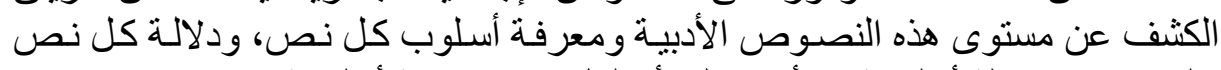

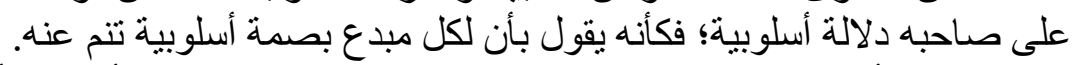

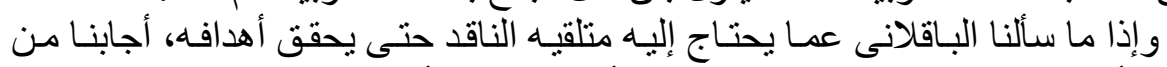

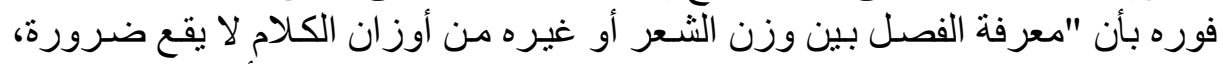

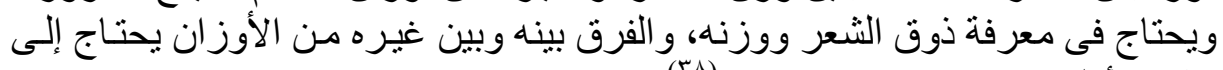

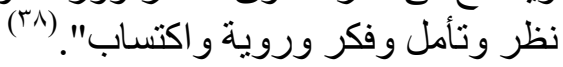




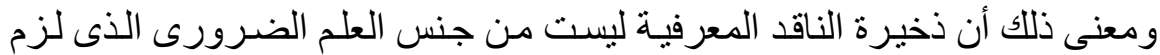

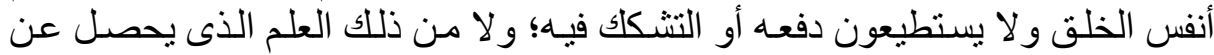

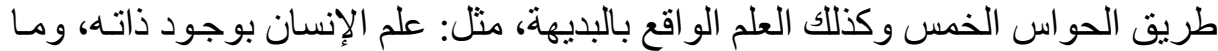

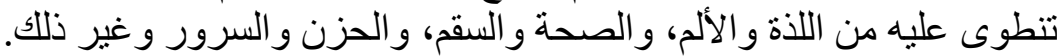

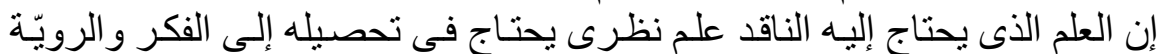

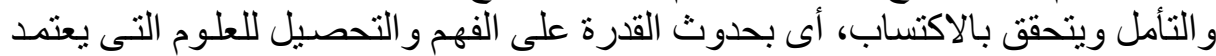

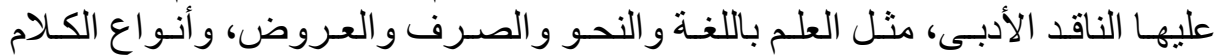

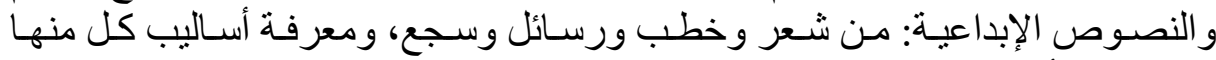

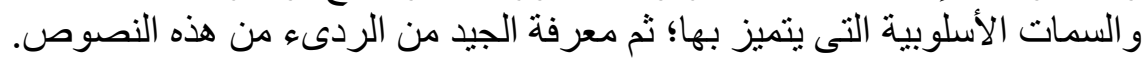

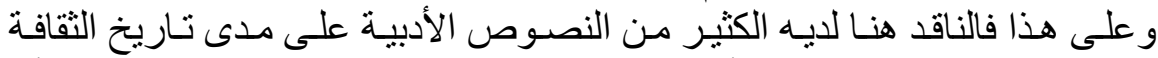

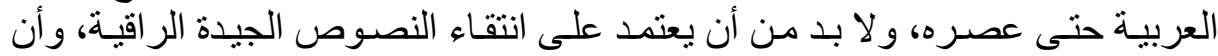

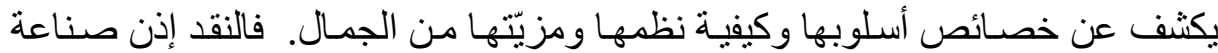

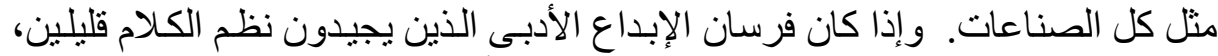

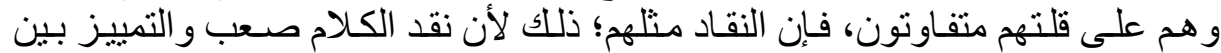

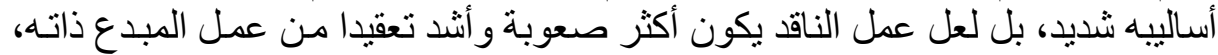

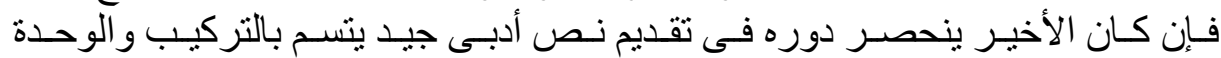

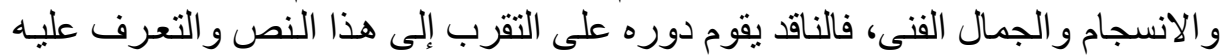

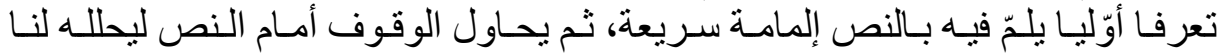

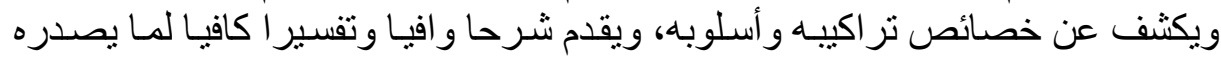

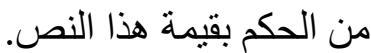
و النقد بهذا يعدّ صنعة، وفى كل صني صنعة تجد تفاوتا بين المختصين بها، من الجاهل

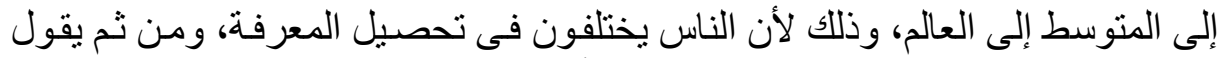

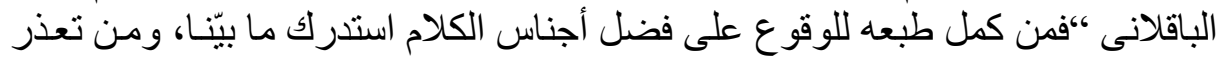

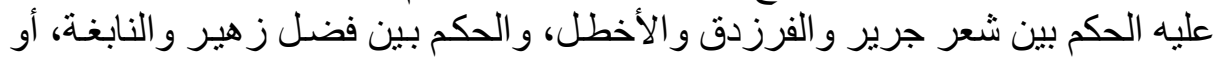

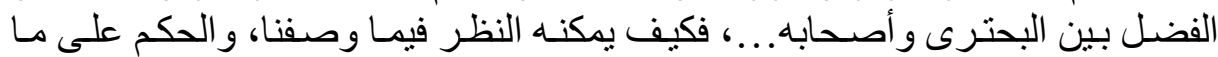
(ب9)" بيّنا. (1)

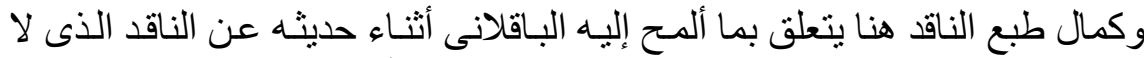

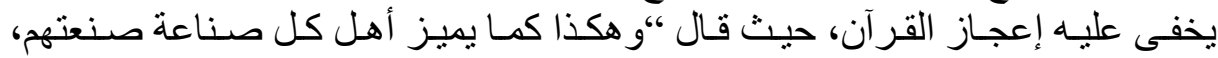

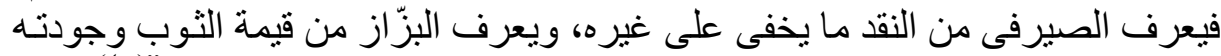

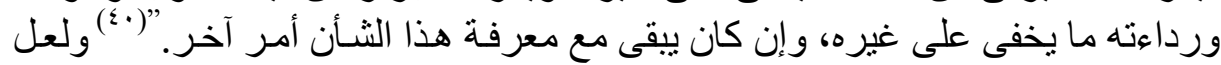

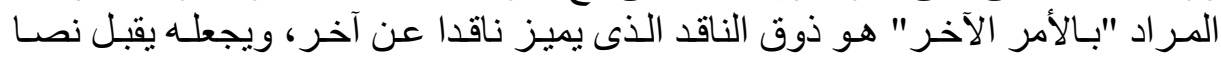
ير فضه الآخر. 
إن ذوق الناقد هو الذى يجعله يتخذ موقفا انتقائيا من النصوص المانتلة أمادهـ ليختار

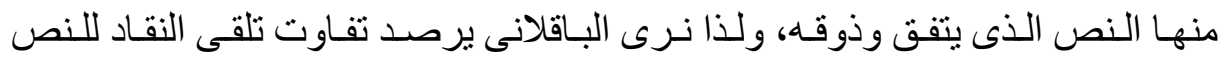

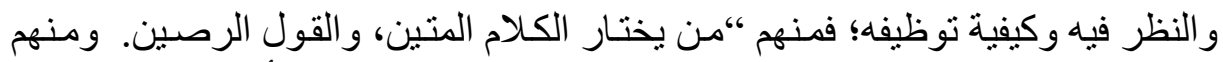

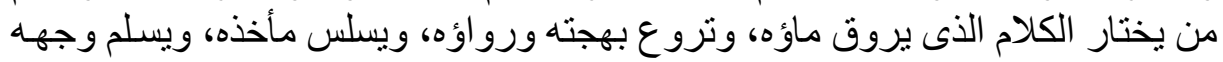

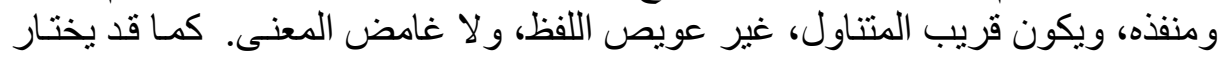

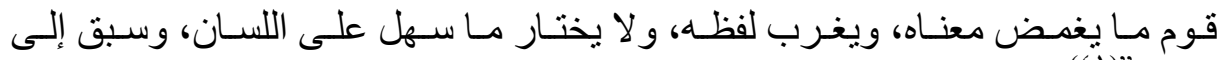

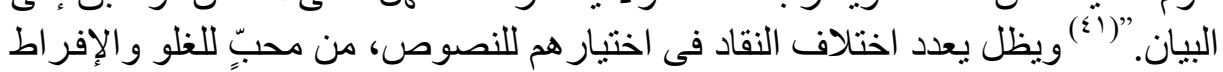

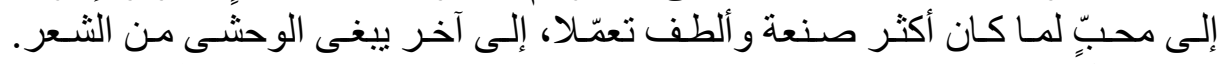

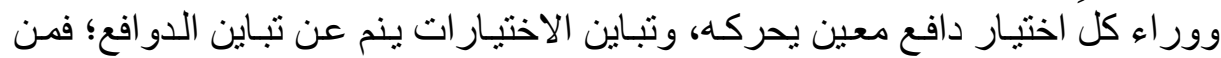

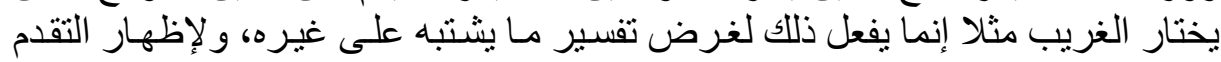
في معرفته و عجز غير هم عند.

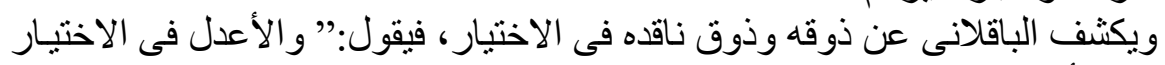

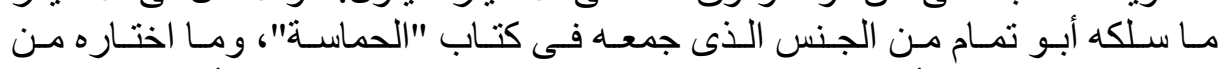

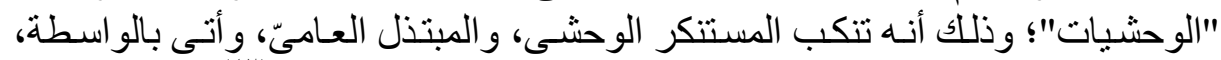

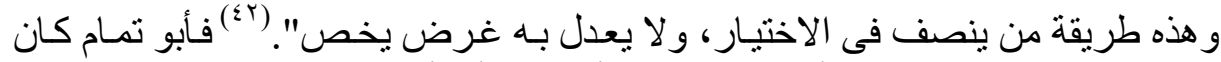

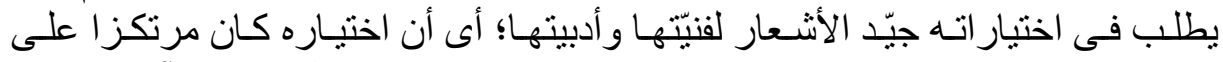

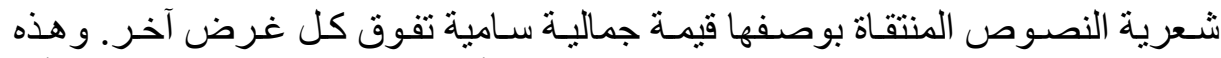

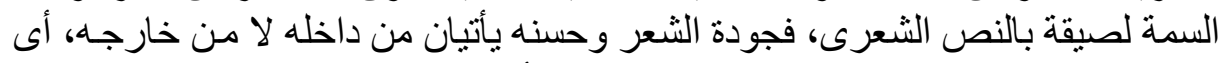

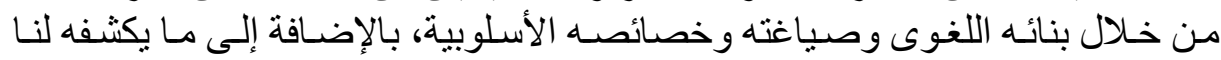

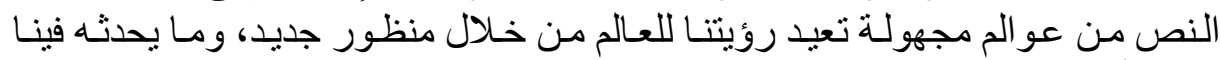

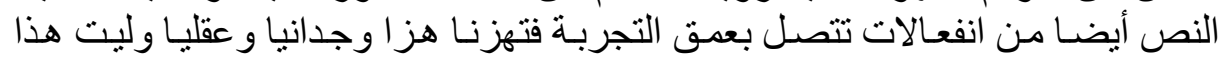

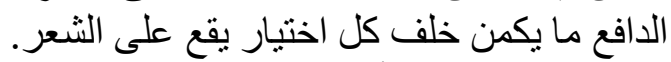

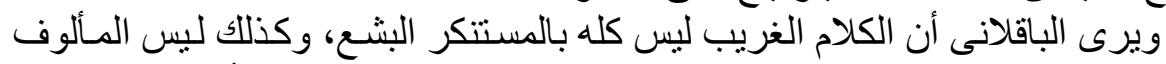

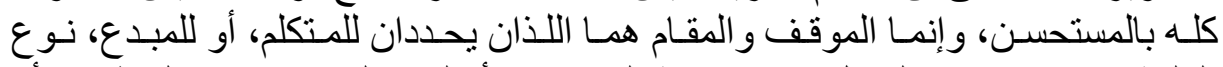

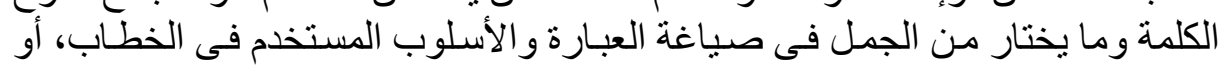

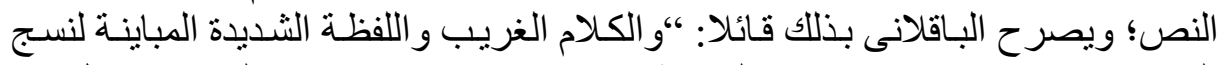

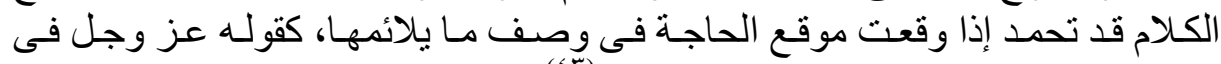

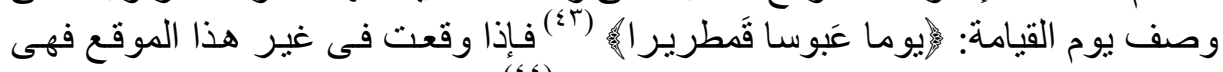

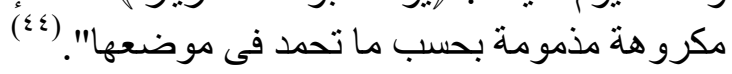

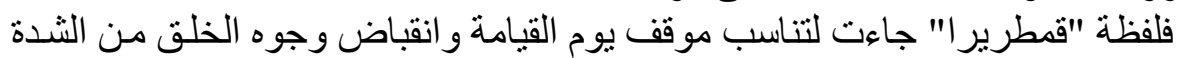

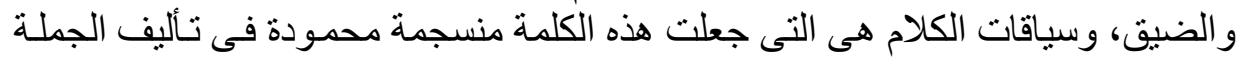

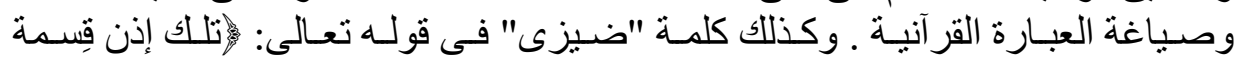




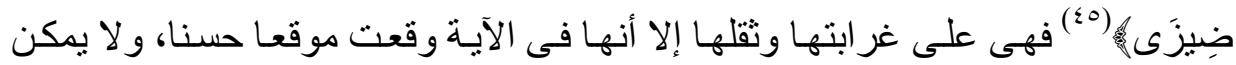

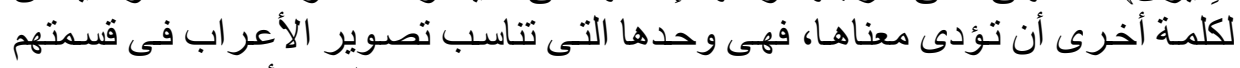

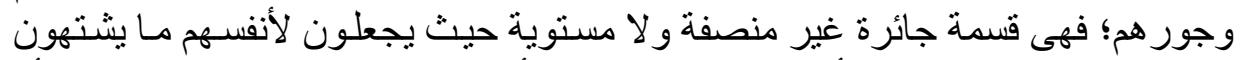

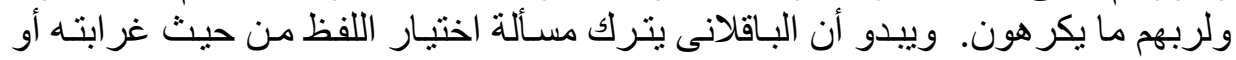

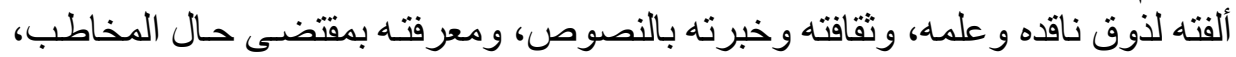

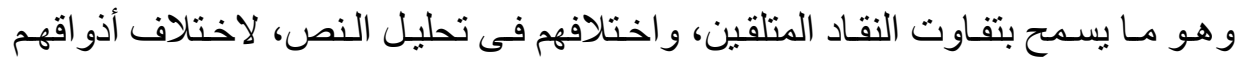
وثقافة كل منهم.

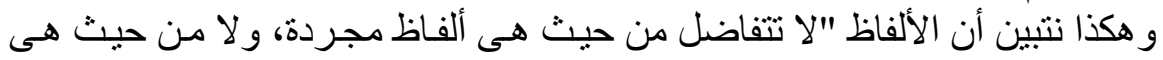

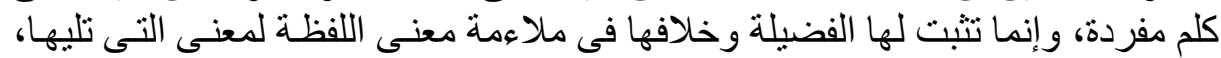

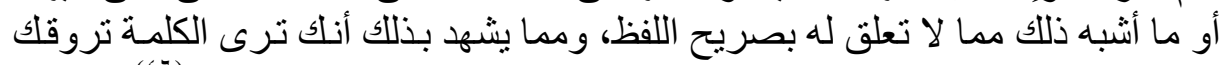

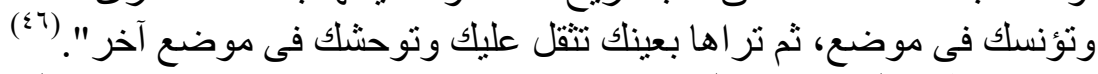

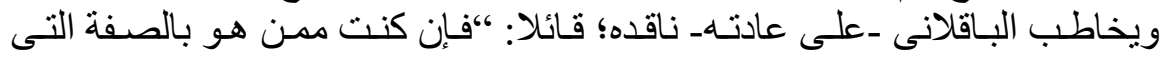

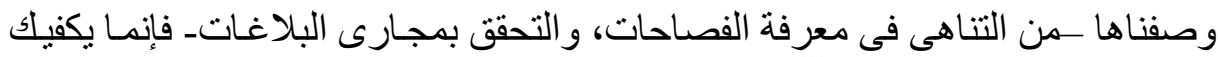

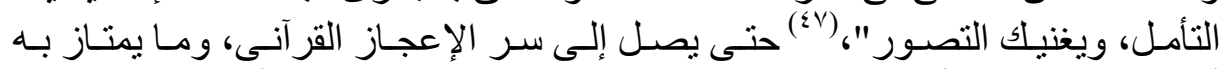

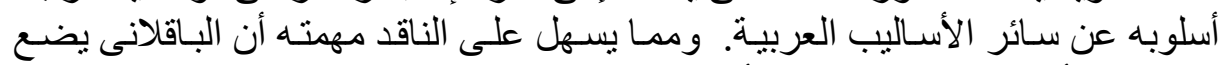

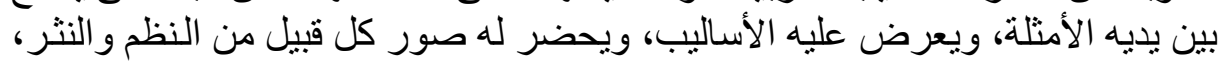

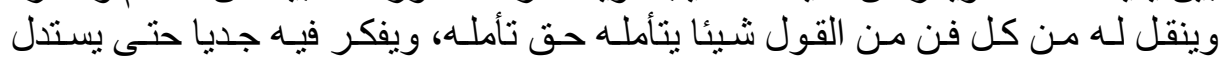
استدلال العالم، ويقع له الفرق بين النظم الفئ القر آنى و الكلام البشرى من كن كل فن.

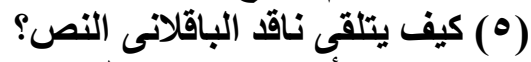

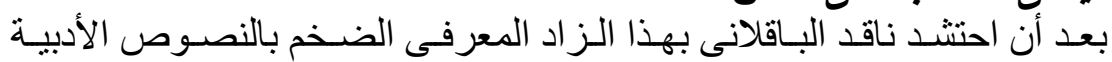

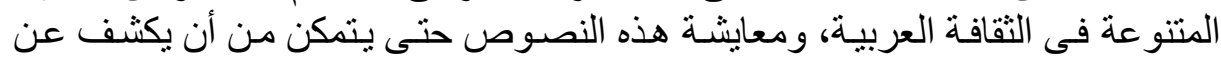

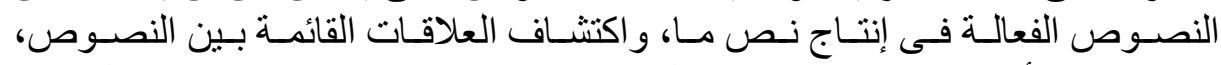

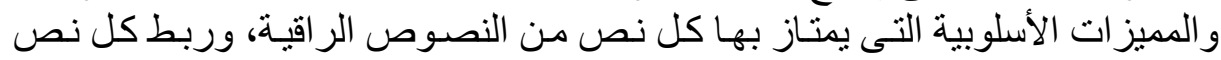

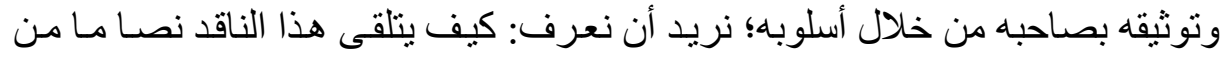
النصوص؟ وتونه بصن أول ما يلقى هذا الناقد من النص هو بنيته السطحية ويشير إليها الباقلانى بألفاظ

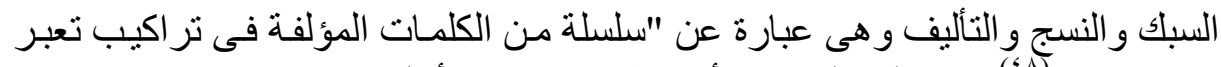

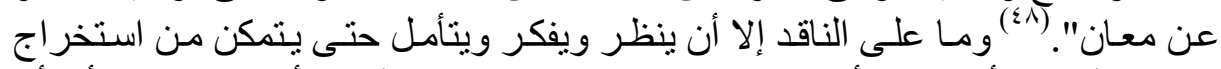

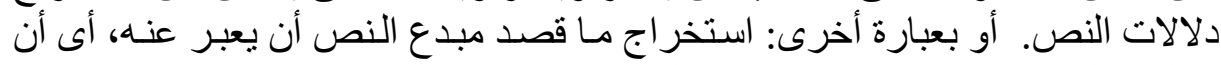

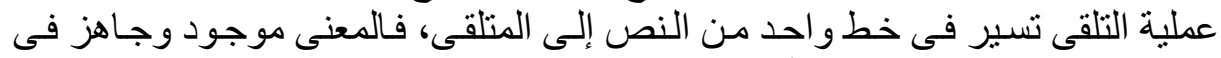

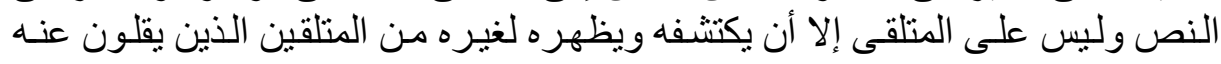
ثقافة ومعرفة. 


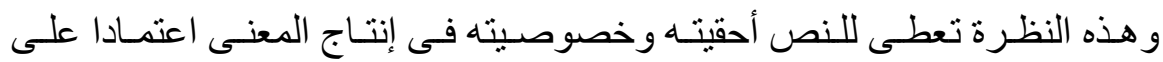

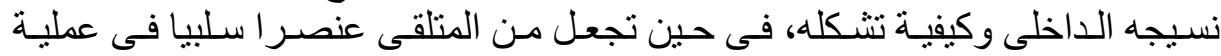

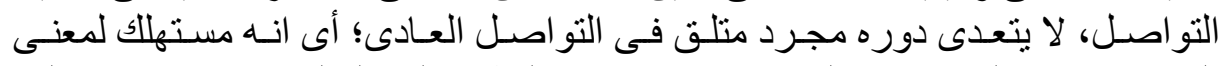

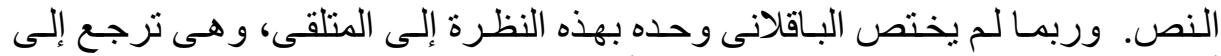

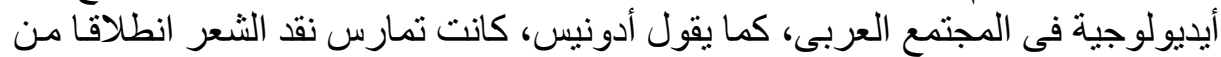

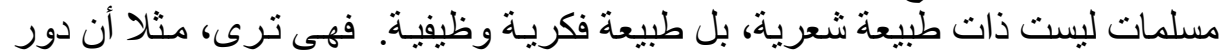

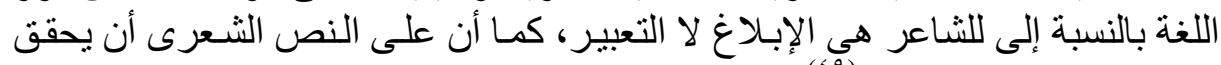

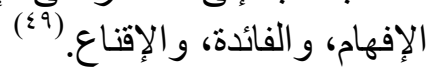

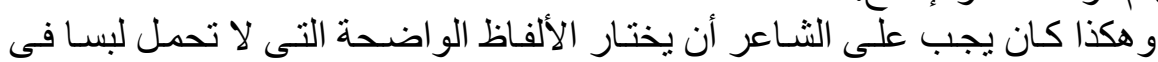

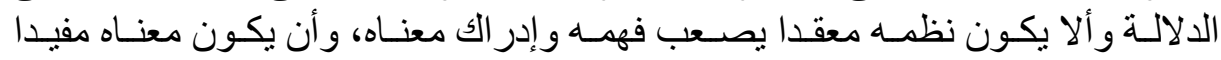

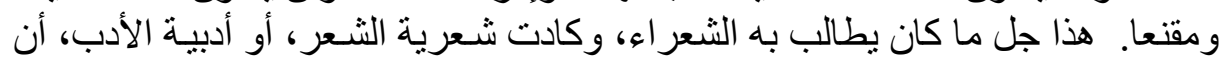
تهمل أو تهمش.

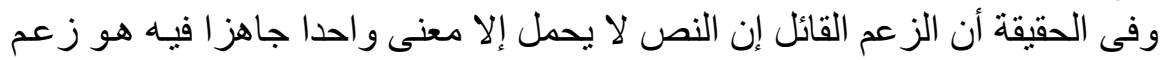

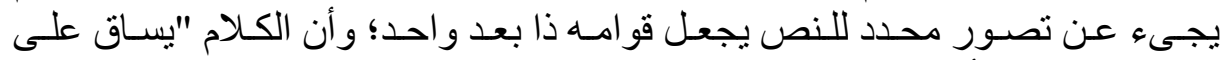

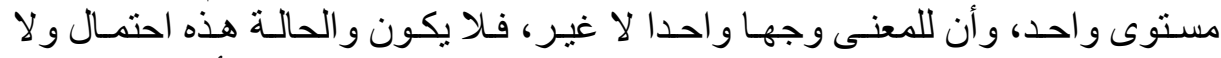

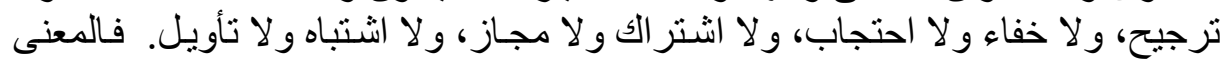

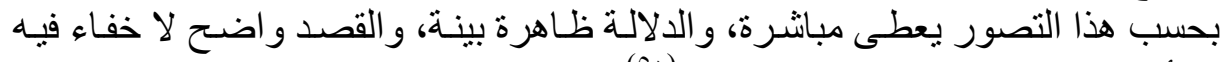

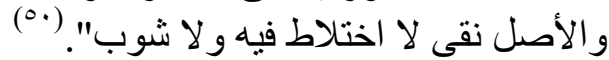

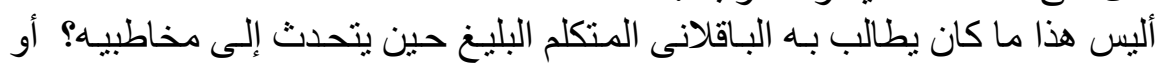

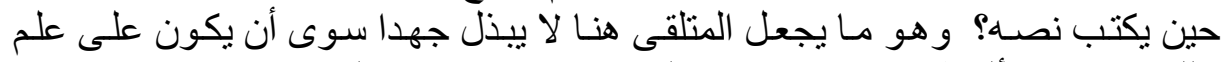

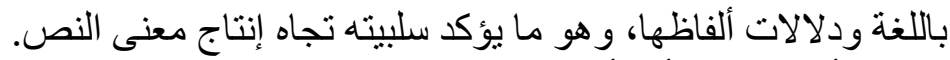

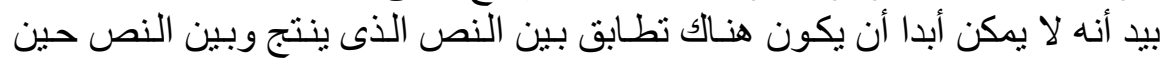

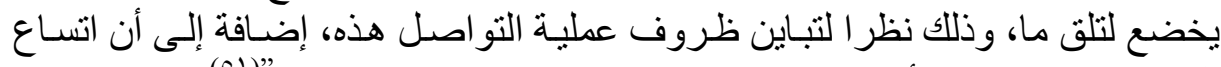

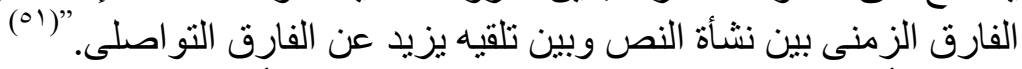

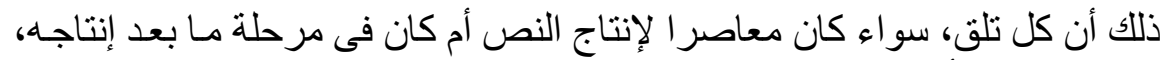

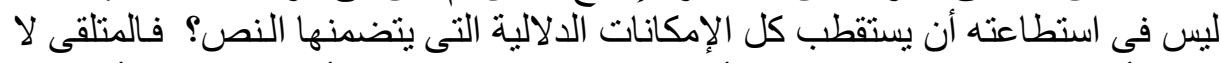

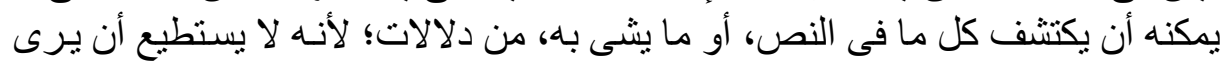

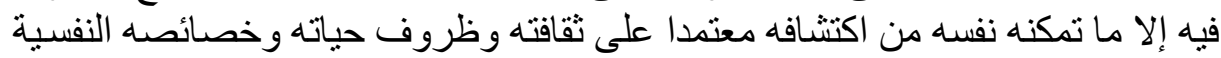

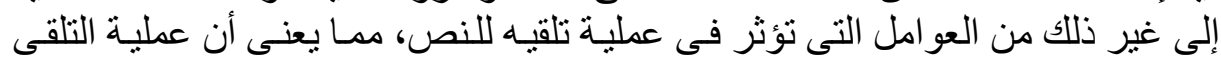

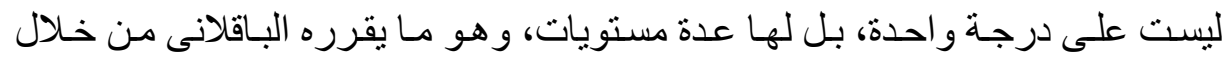
حديثه عن تفاوت المتلقين ثقافة وذورة بها وخبرة. 


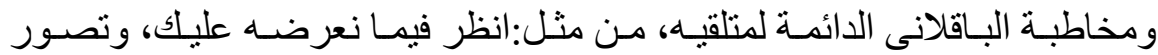

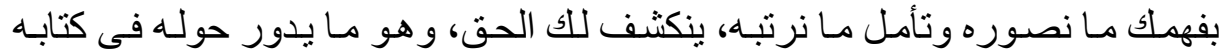

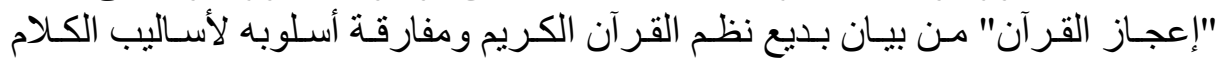

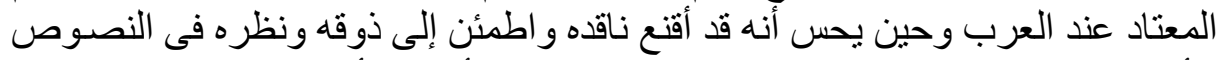

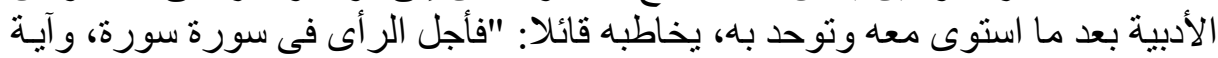

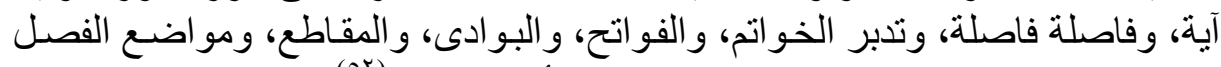

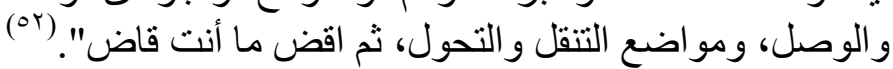

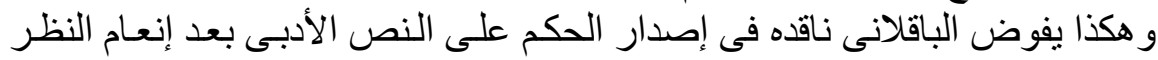

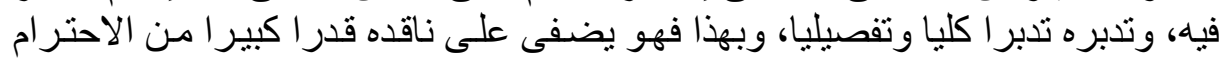

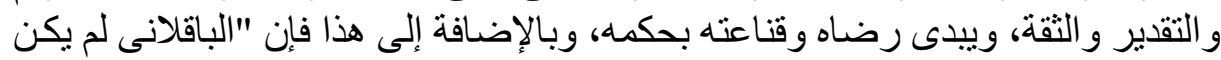

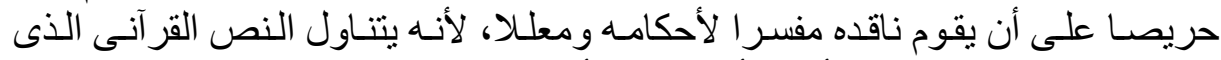

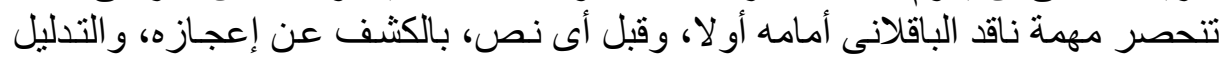

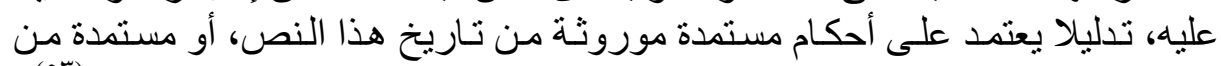

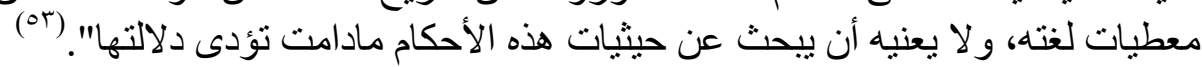

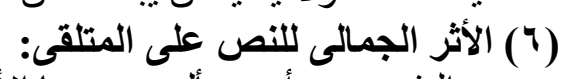

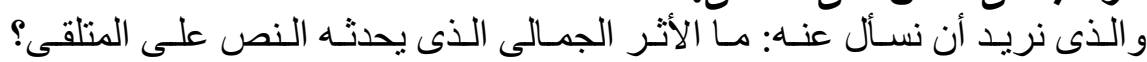

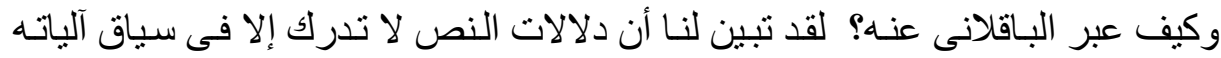

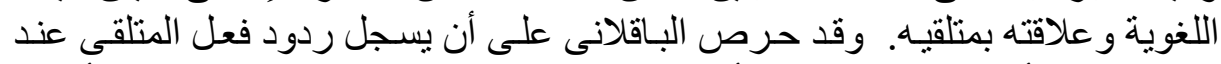

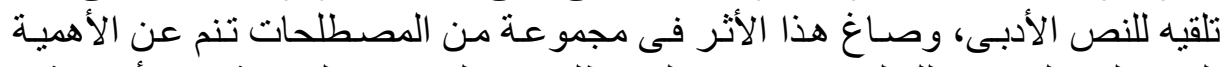

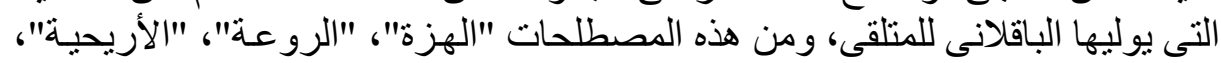

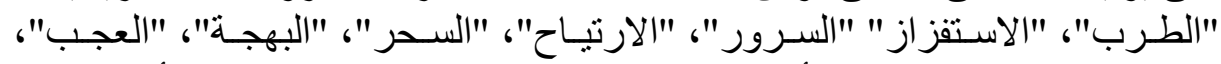

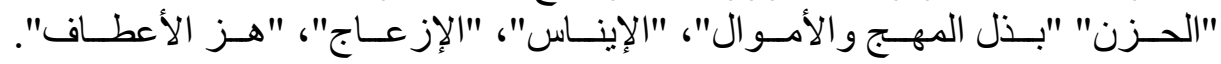

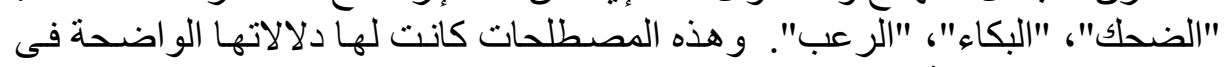

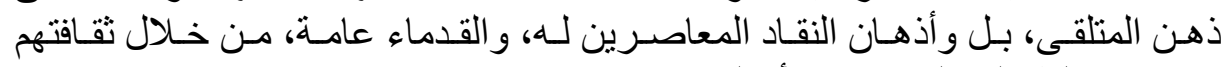

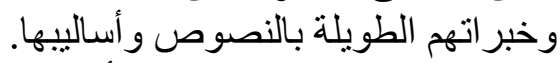

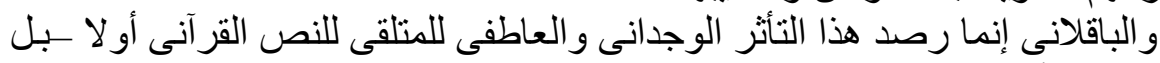

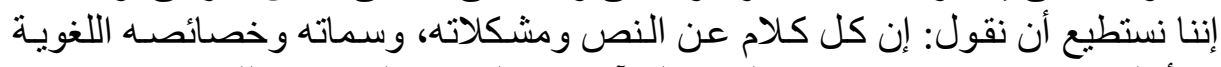

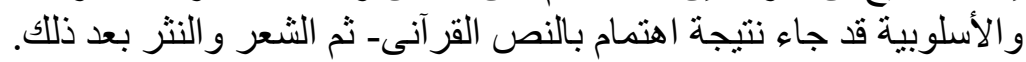

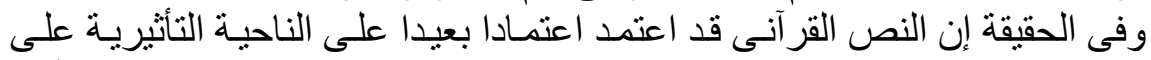

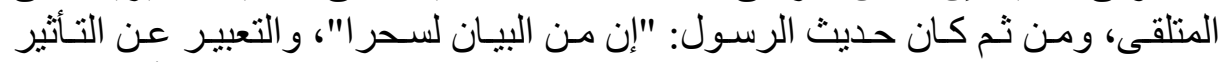

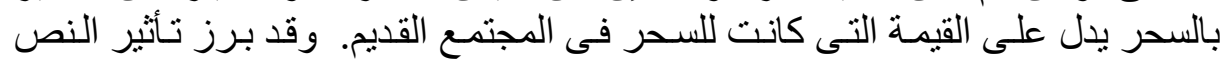

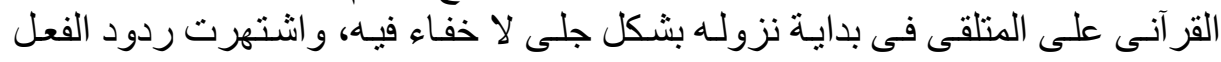




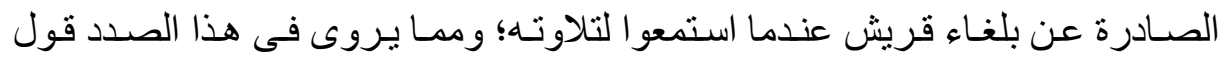

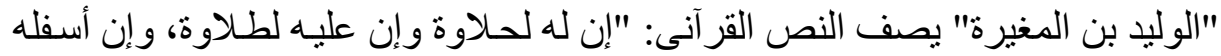

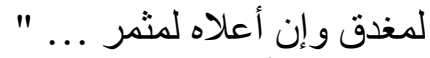

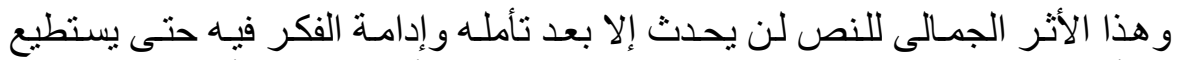

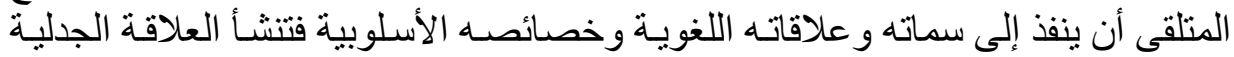

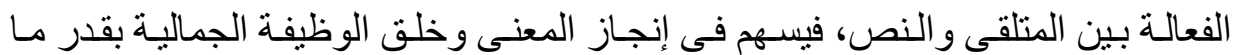

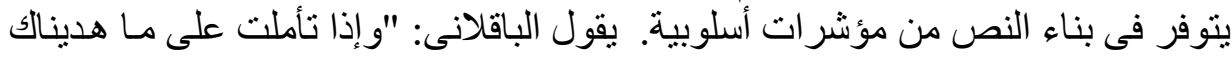

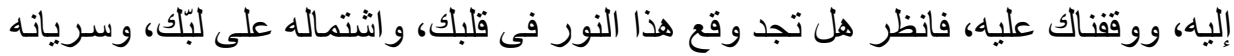

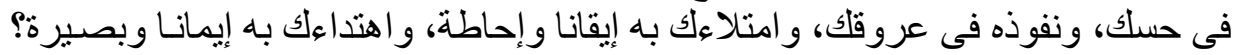

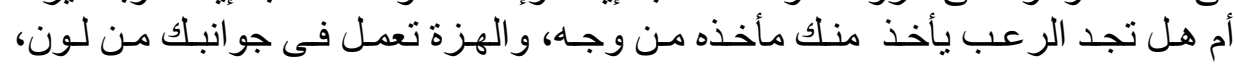

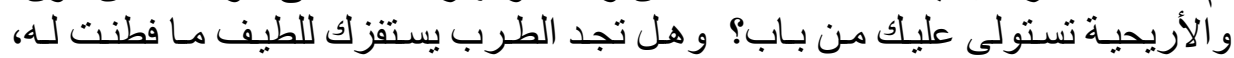

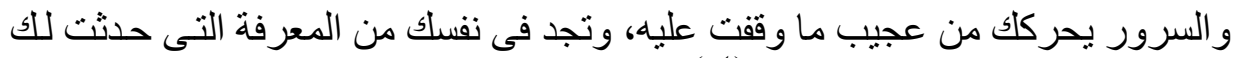

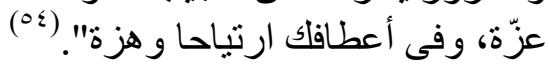

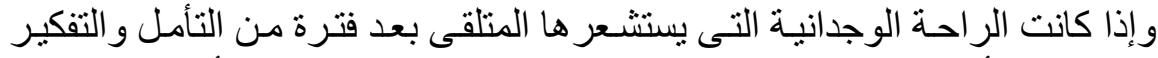

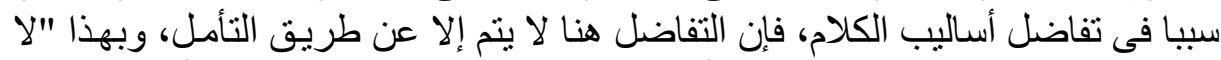

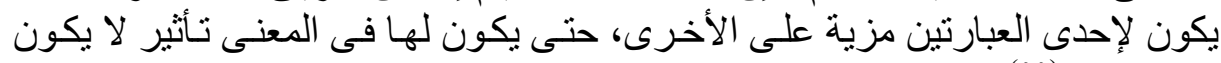

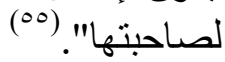

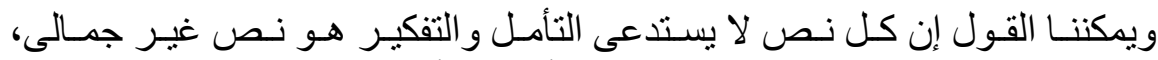

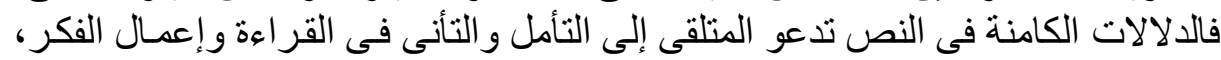

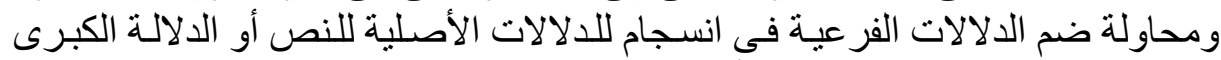

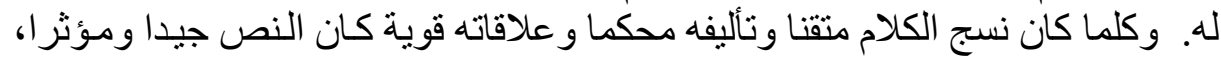

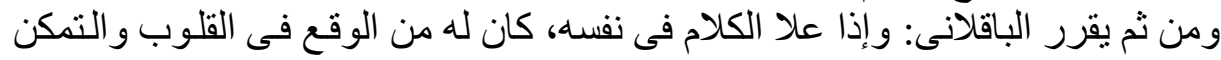

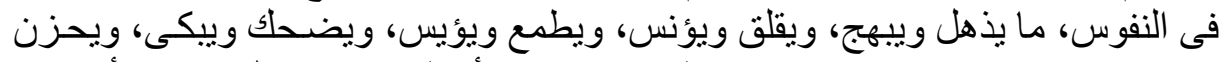

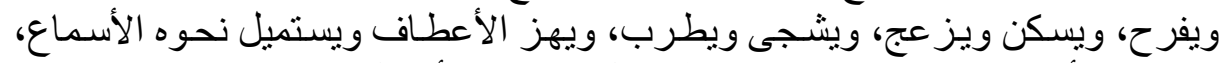

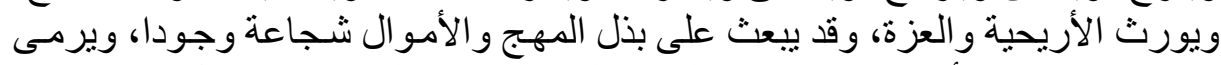

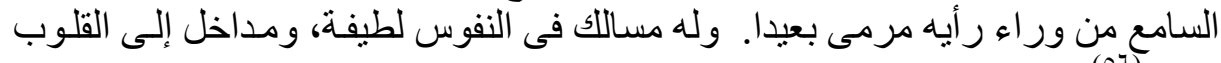
دقيقة.

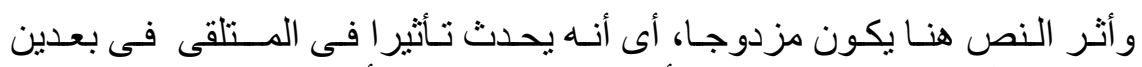

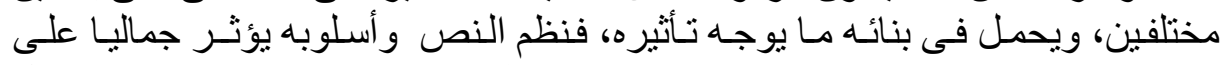

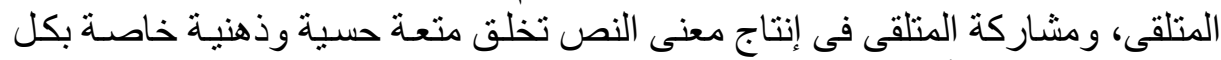

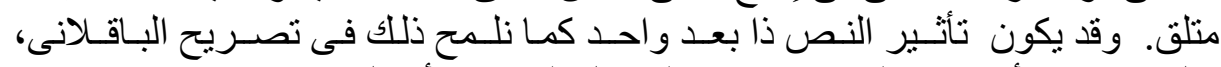

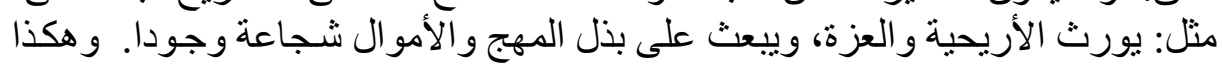




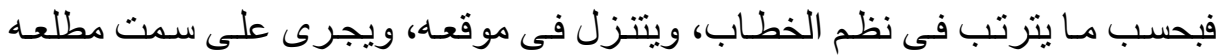

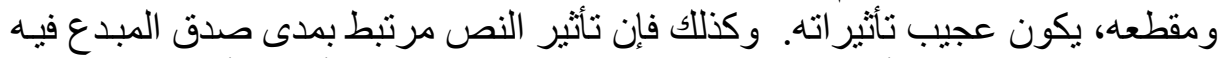

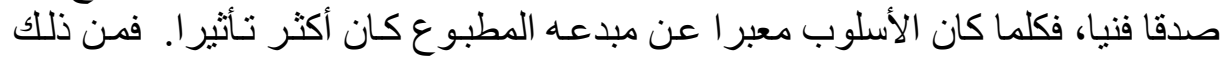

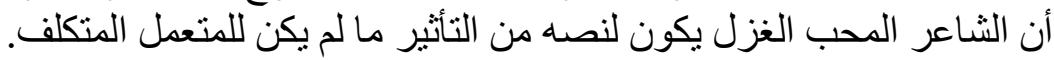

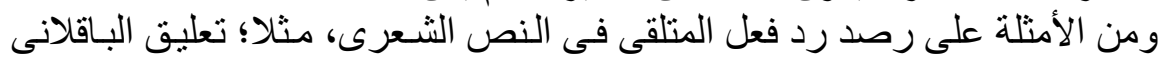

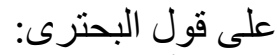

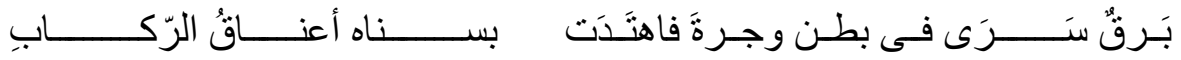

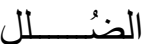

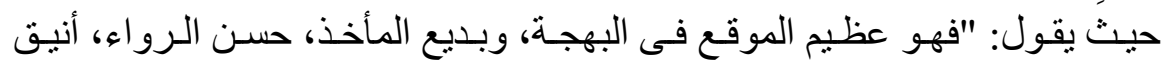

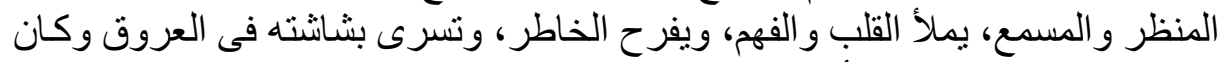

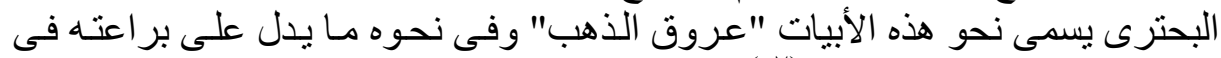

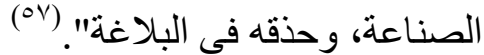

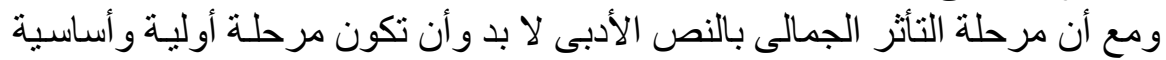

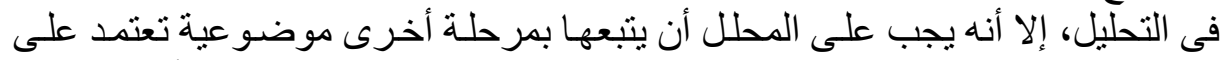

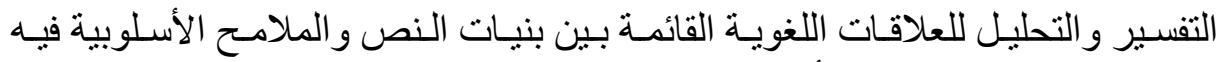
ومدى توظيفها فى إحداث التأثير وجدانيا وذهنيا.

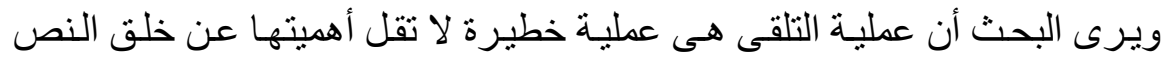

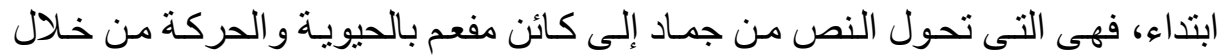

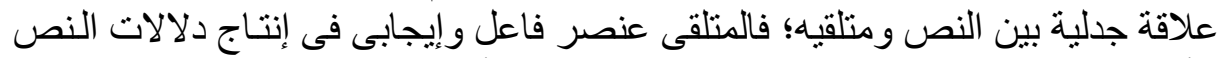

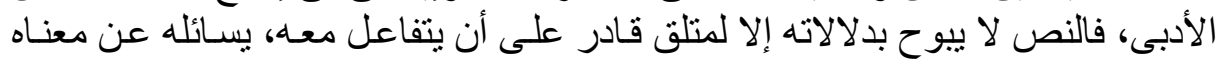

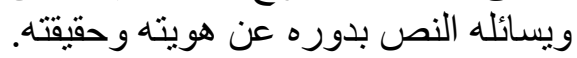

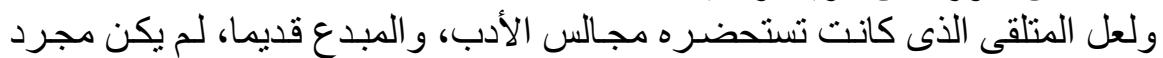

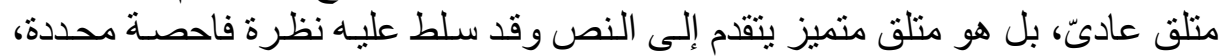

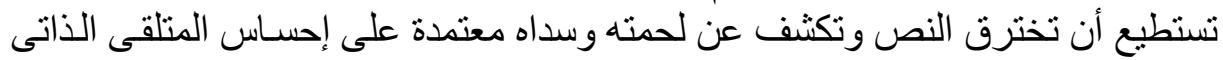

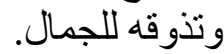

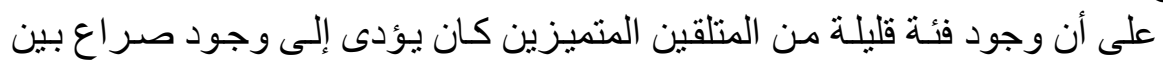

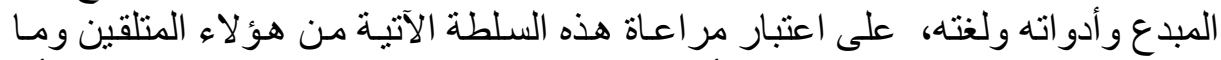

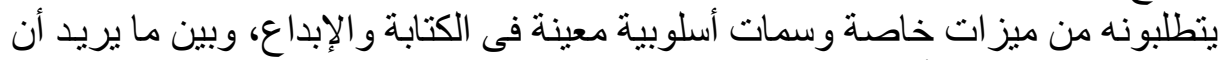
يعبر عنه المبدع من أفكار ومشناعر.

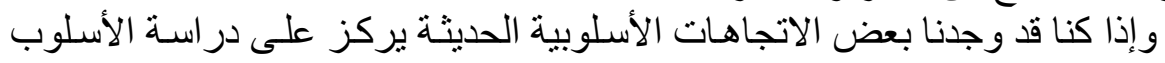

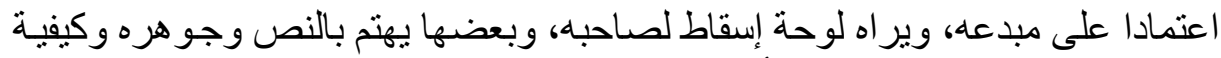

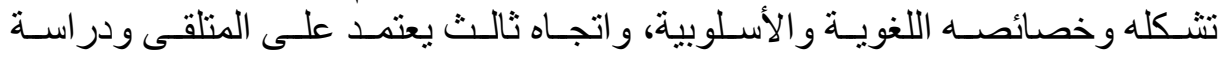




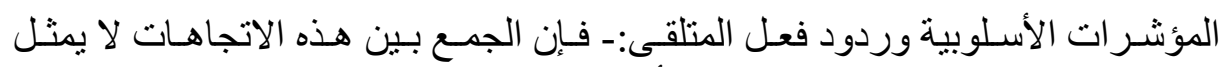

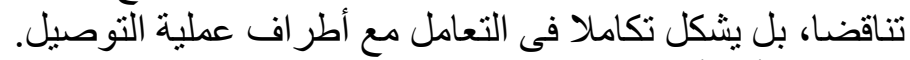

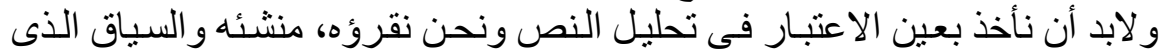

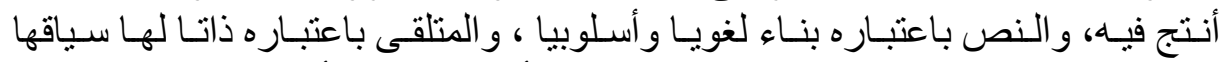

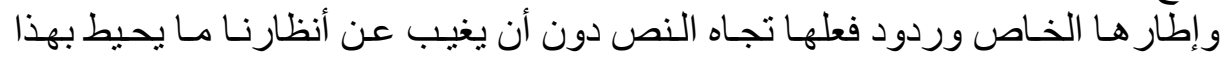

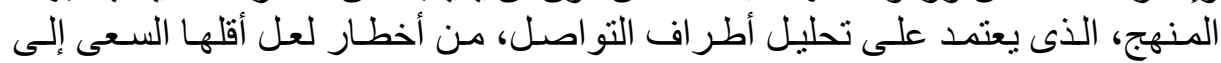
الثمول. 
(1) راجع: روبرت هولب: نظرية التلقى، ترجمة عز الدين إسماعيل، النادى الأدبى الثقافى بجدة 9V،

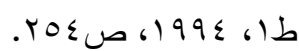

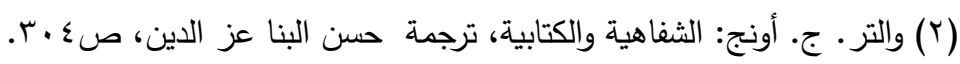

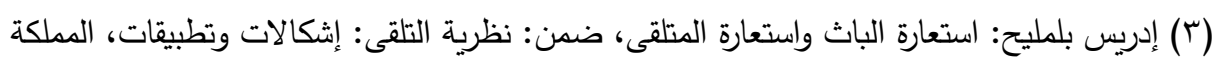

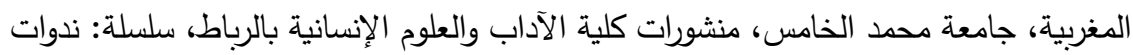

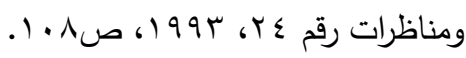

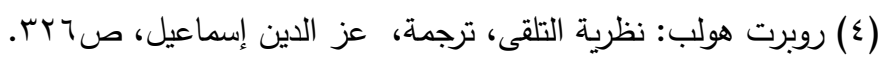

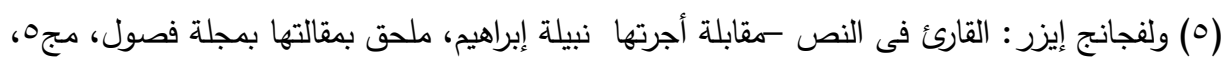

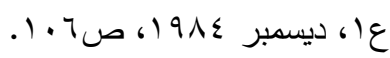
(7) الحبيب شبيل: من النص إلى سلطة التأويل، ضمن مجلد ^، صناعة المعنى وتأويل النص، سبق

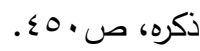

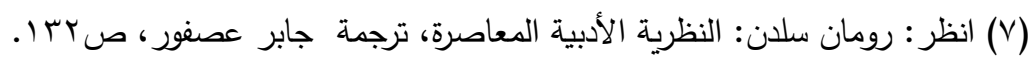

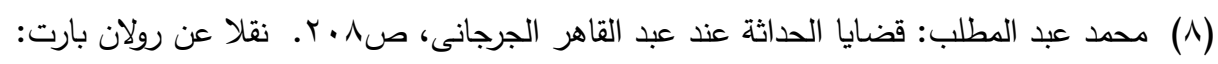
درس السيميولوجيا.

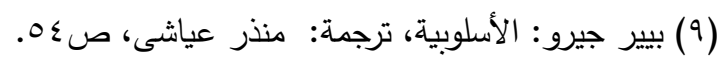

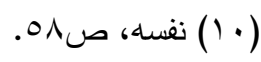

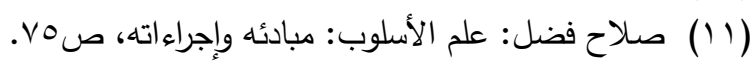

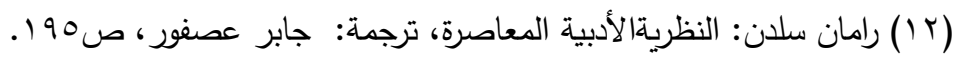

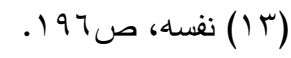

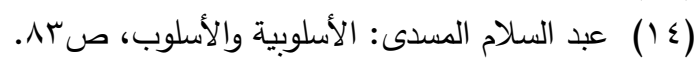

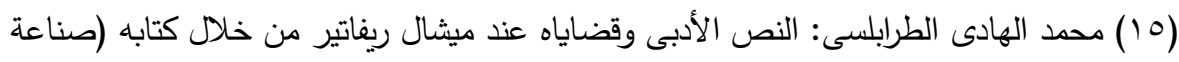

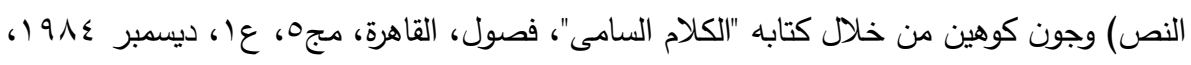
صسזו.

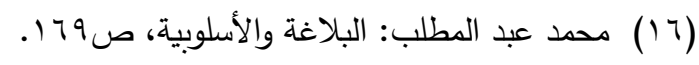

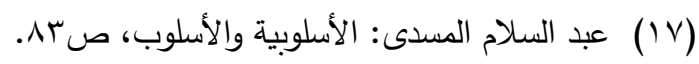

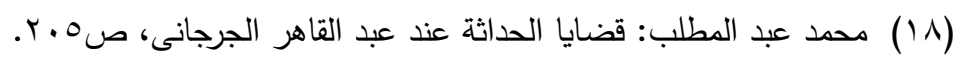

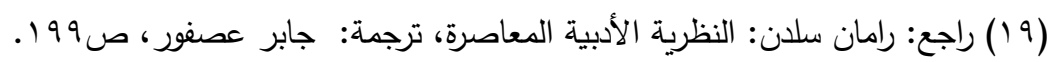




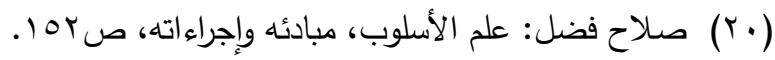

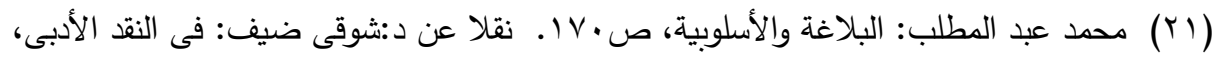

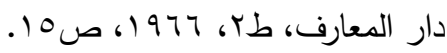

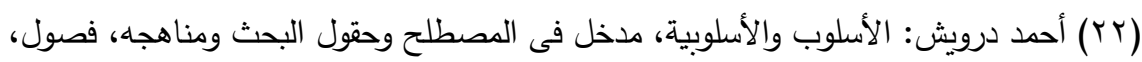

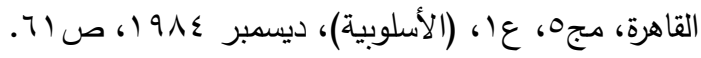

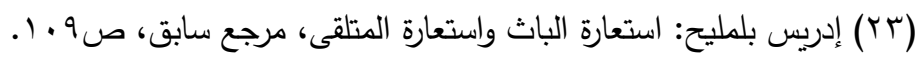

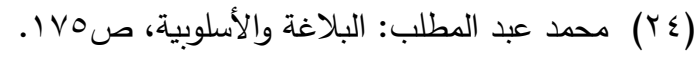

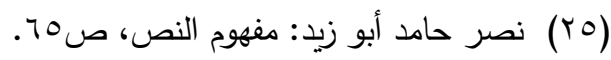

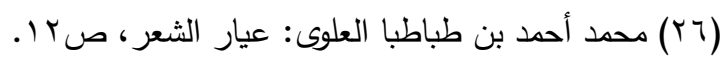
(YV)

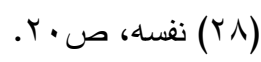

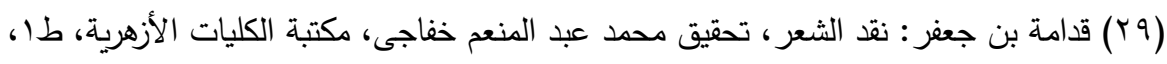

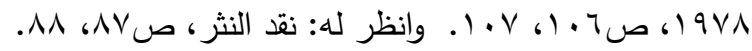

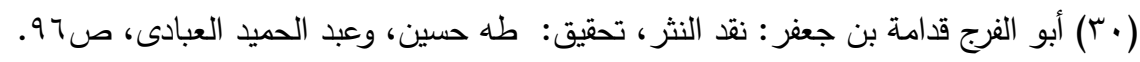

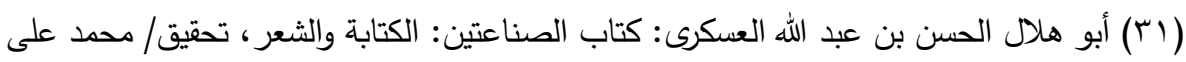

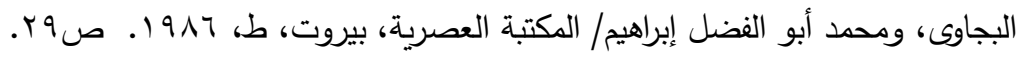

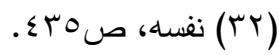

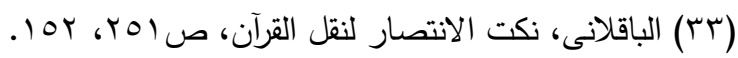

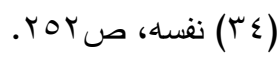
( ( )

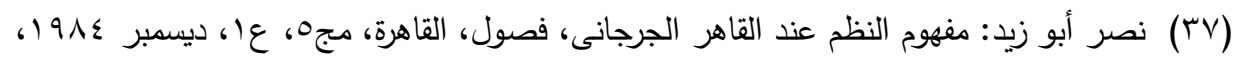




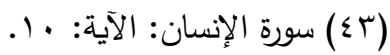

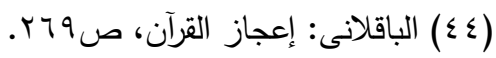

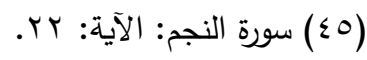

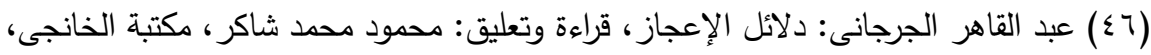

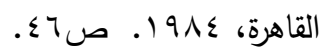

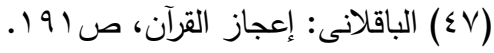

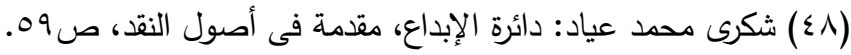

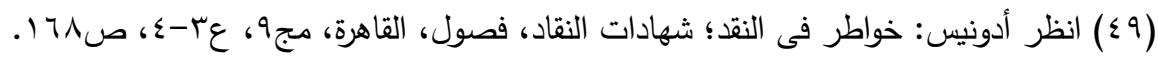

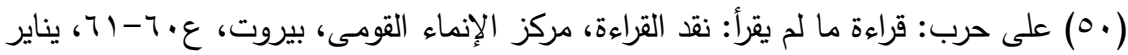

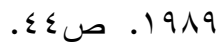

(0) كونتر جريم: التأثير والتلقى؛ المصطلح والموضوع، ترجمة وتقديم: أحمد المأمون، دراسات

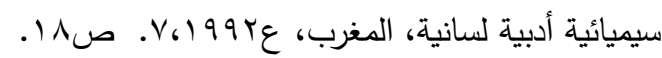

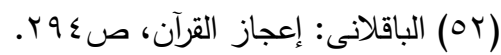

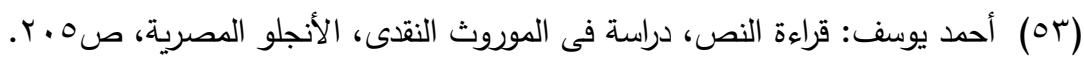
( (

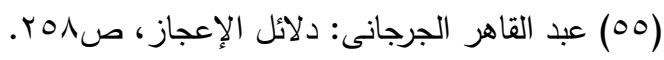

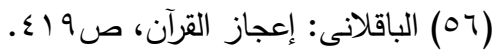

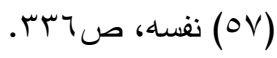

